\title{
EL ESPACIO EN LA ARQUITECTURA RELIGIOSA VIRREINAL DE MÉXICO
}

\section{Por Manuel González Galìán}

EL ESPACio es objeto de gran significación para nuestra época, su análisis y máximo aprovechamiento nos es vital, hoy, cuando las rápidas comunicaciones lo acortan y la sobrepoblación congestiona las ciudades.

La arquitectura contemporánea, percibiendo el impacto de esta civilización expansiva abandona su tradicional desarrollo horizontal y se repliega en verticales absorbentes, en colosales edificios que superponiendo niveles lanzan al espacio lo que la superficie ya no puede contener.

El antes primordial aprovechamiento de la extensión cede paso a la utilización del volumen. La apreciación de plantas en desarrollo bidimensional, al dominio de los alzados tridimensionales. El expansionismo es, por necesidad, una de las grandes características de nuestro siglo, consecuentemente, la apreciación de los valores espaciales ha sido una de las preocupaciones de la crítica moderna del arte, así como la revisión de las soluciones espaciales del pasado, tema de apasionado interés, a tal grado, que hablar de espacios parece estar de moda. Ello es solamente la natural consecuencia evolutiva de la misma crítica que al buscar respuesta a problemas que siendo actuales no son precisamente nuevos, encuentra la explicación en el posible aprovechamiento de las experiencias del pasado. Así, la crítica se justifica y se hace necesaria históricamente cuando supera la simple elucubración arqueológica y alcanza una relación vital; búsqueda y descubrimiento que a su vez le sirve de apoyo para estimar los valores intemporales del arte. ${ }^{1}$

1 Como en seguida se verá con claridad, nosotros somos partidarios de una posición moderna, y desprejuiciada en la historia de la arquitectura, y de una actualización de la cultura tradicional a la luz del pensamiento arquitectónico moderno. Pero el método de estos arquitectos frente a los monumentos no es el de una seria investigación moderna; la antiacademia si no en las declaraciones, en los hechos, ha llevado demasiado a menudo a la anticultura, es decir, a la antihistoria. Si la lucha contra la decoración debía conducir necesariamente a un desinterés por los valores decorativos de la arquitectura tradicional, ¿qué decir de los valores volumétricos propugnados por el funcionalismo, y de los valores espaciales propugnados por la tendencia orgánica? Una vez afirmada una conciencia moderna en la arquitectura, es lógico revelar lo moderno en lo antiguo. La academia dice: "Estudia lo antiguo 
En la actualidad hay un conocimiento más amplio y directo de los monumentos por ser más fácil el acceso a ellos y estarse enriqueciendo cada vez más la documentación histórica y estilística, por ello la crítica, acorde con las inclinaciones propias de la época, se interesa hoy especialmente por la razón de ser de los espacios arquitectónicos.

Por la historia sabemos cuándo se hicieron los monumentos, por la estilística cómo se hicieron y el círculo de comprensión sólo queda cerrado al entender por qué se hicieron así. El porqué dieron determinada configuración espacial sus creadores a nuestros monumentos novohispanos es justamente el motivo de las observaciones anotadas en esta parte del ensayo. De una manera tan superficial como fácil ha sido acusada la arquitectura novohispana de ser tan rica en imaginación decorativa como aburrida, monótona y falta de vitalidad en la disposición de plantas y alzados, es decir, en lo que atañe directamente a la configuración espacial. Al estudiarla y analizarla asł se hace una disociación de sus valores y se concluye que siendo un arte predominantemente suntuario adolece de pobreza en los más esenciales valores arquitectónicos, aceptándose, sin embargo y sin reparo, la contradicción de que fue un arte de imaginación fecunda en lo ornamental y pobre a la vez en las estructuras, o sea, que variedad y monotonía corren paralelas. $Y$ si el rico aprovechamiento de lo ornamental en contraste con las estructuras estereotipadas no puede ser negado, sí, en cambio, debe ser explicado, pues sería tanto como aceptar una desconcertante conciencia-inconsciente de sus creadores. Sin duda la consideración del problema nos llevará a entender ese contraste, al sondear la intención voluntaria con que este arte administró y jerarquizó, de acuerdo con sus fines, los diversos ingredientes formales que lo integran.

Esta falta de objetivación de la arquitectura virreinal, ha creado el prejuicio de su anquilosamiento arquitectónico, prejuicio justificado, generalmente, por tomar como referencia la esplendorosa movilidad estructural alcanzada por el arte europeo, sobre todo, en la época barroca. Se insiste demasiado en ver nuestro arte desde el punto de vista "colonial", es decir, de trasplante, de sujeción, como un arte mimético de los patrones del viejo mundo. Por ello, la decoración que aquí evolucionó a la par y hasta superó en abigarrado esplendor la producti-

para hacer lo nuevo" -o bien- "En lo antiguo está lo nuevo." Nosotros decimos exactamente lo contrario: "Profundiza lo moderno, individualiza sus valores, para poderlos encontrar de nuevo en la arquitectura antigua, y asi amarla." Bruno Zevi, Saber ver la arquitectura. Ed. Poseidón. Buenos Aires, 1958, nota 4, p. 137. 
vidad europea, se lleva toda la atención y el aplauso y se la puede mostrar con justificado orgullo nacionalista. ${ }^{2}$ En cambio, la impasible y reiterada repetición de plantas y alzados convertidas en dogmático canon durante tres siglos es observada con desaire o se la calla prudentemente como un pecado que se trata de olvidar; sobran dedos de la mano para citar, entre los miles de ejemplos "coloniales", las plantas movidas y "verdaderamente barrocas". Por otra parte, la prácticamente nula bibliografía y las escasas referencias al sentido espacial de la arquitectura virreinal parece mostrar que este aspecto no fue objeto de preocupación, ni en su tiempo, ni posteriormente. Así, Ia investigación resulta más difícil en este tema, pues por inexplorado se corre el peligro de perderse, de caer fácilmente en una arbitraria elucubración personal o en una emotiva e ilusa distinción espacial inexistente.

Podemos aprovechar la abundante crítica acerca de la arquitectura europea, tan medida y analizada, y justamente apoyarnos en ella como término comparativo, buscando poner de relieve más las diferencias que las naturales similitudes, con el fin de encontrar por contraste las diferentes distintivas. Sin pretender con ello la superioridad o inferioridad de un arte $u$ otro, se trata de señalar sencillamente lo distintivo, puesto que está suficientemcnte demostrado que la influencia europea no eclipsó, sino antes bien promovió, la capacidad creadora en estas tierras, de las que se puede decir - con Burckhardt- que "verdaderamente grande lo es la nación que toma mucho de los demás y lo transforma en substancia propia".

Justamente apreciando los valores originales del arte europeo y comparándolos con los nuestros se hace patente el grado de influencia, pues lo que en Europa brilla y no se encuentra aquí nos da su límite de continuidad y el grado de resistencia local a las influencias. Esa resistencia se forta-

2 "Si en los más viejos edificios americanos de inspiración española las normas metropolitanas apenas se modifican con algún acento provinciano debido a la interpretación de los frailes arquitectos o a la mano de obra indigena, en el barroco la América virreinal, encuentra su más adecuada expresión arquitectónica y crea tipos de poderosa originalidad y de singular belleza, que no solamente superan a lo europeo contemporáneo, sino que a veces, se proyectan sobre ello para reavivar la tradición fatigada y enriquecerla con nuevas aportaciones.

... resulta una arquitectura de inigualable riqueza morfologica cuyo reciente conocimiento ha causado en los medios europeos verdadero estupor.

"El antiguo virreinato de Nueva España es acaso, en todo el mundo, uno de los centros más importantes de arquitectura barroca, que sólo aquí es llevada hasta las últimas consecuencias." Marqués de Lozoya, Historia del arte hispdnico. Ed. Salvat. Barcelona, Buenos Aires. 1945, vol. Iv. pp. 223-224. 
lece tras un decidido empeño de claridad e inmovilidad espacial, que siendo tradicionalmente mexicano delata, con su presencia activa, durante el curso de los tres siglos virreinales y aún hasta nuestros días, algo que podriamos llamar, parafraseando a Worringer, una mexicana "voluntad de espacio" o también la reafirmación de esa "mismidad" que Chueca Goitia justamente considera como una prueba de personalidad y fuerza, no de un estilo en particular, sino en términos más amplios, de una forma de cultura. *

\section{EL SIGLO XVI}

Asombra comprobar cómo unos cuantos años después de la Conquista, los trazos urbanos de México tienen ya un definido carácter propio, que se dintingue por la organización arquitectónica en torno a espacios muy amplios, delimitados ya sea por conjuntos religiosos, como en el caso de los conventos y sus atrios, o bien por disposiciones urbanísticas, como en las ciudades con sus catedrales, parroquias y palacios en relación a las plazas. En la composición del espacio hubo una fusión clara del sentido organizador hispánico con la sensibilidad indigena para lograr la grandiosidad. La "traza moderada" de 1539, dictada por el virrey Antonio de Mendoza de acuerdo con los provinciales de las órdenes monásticas, y las "Ordenanzas sobre descubrimiento nuevo y población", dictadas por Felipe II, en 1563, fueron engendradas y nacieron precisamente obligadas y configuradas, porque habia que encauzar la pujanza americana. El siglo dieciséis logró la conjunción, con sorpresas mutuas; para el indígena, la novedad de la arquitectura europea, con sus muros y bóvedas capaces de aprisionar inmensos espacios interiores y hacerlos sensibles, como a una escultura en negativo delimitada por la "caja mural"; para el europeo, la novedad del espacio abierto arquitecturado, el descubrimiento de la funcionalidad de lo no cubierto. Así surgen los conjuntos conventuales en los que como centros ceremoniales prevalece la disposición prehispánica, con la mole de la igle-

* "Nos apoyamos, pues - tal creemos-, sobre un hecho, un factum, y no una entelequia; sobre una comunidad de hombres que viviendo en una misma tierra, un destino común, se han representado el mundo de una cierta manera.

Las ligaduras, los vínculos que han unido y que unen a estos hombres son estrechos, son reales; comunidad de suelo, sangre, historia, lengua. Forman una casta histórica que, puesto que existe, expresa su propia mismidad, por la vía del arte, que es la que ahora aqui nos interesa." Fernando Chueca Goitia. Invariantes Castizos de la Arquitectura Española. Editorial Dossat, S. A. 1947. p. 10. 


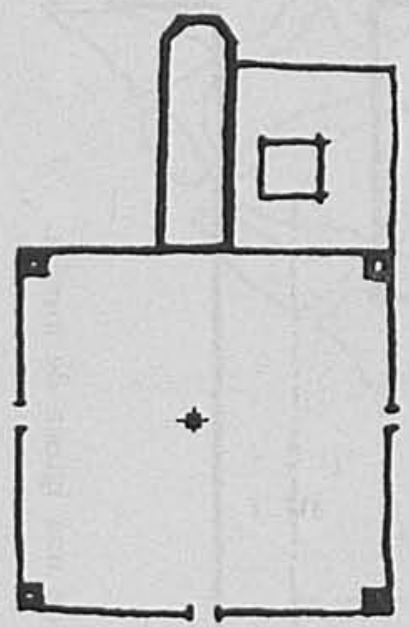

1. Convento Siglo XII México.

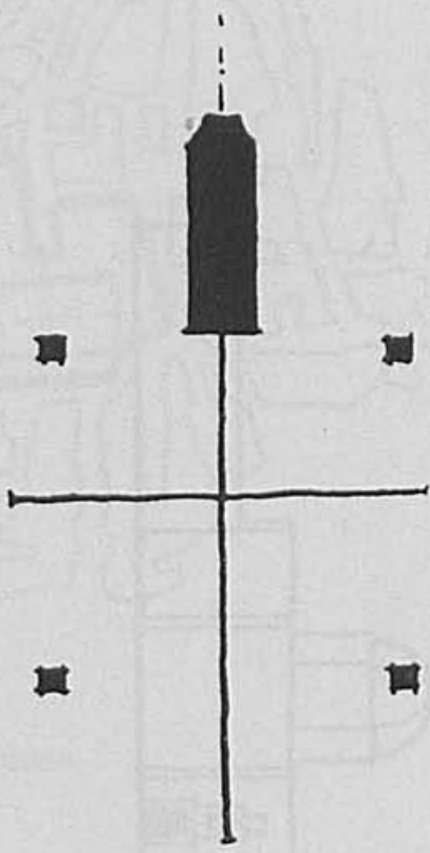

2. Distribución iglesia y posas. Siglo XVI. 
DOI: http://dx.doi.org/10.22201/iie.18703062e.1966.35.824
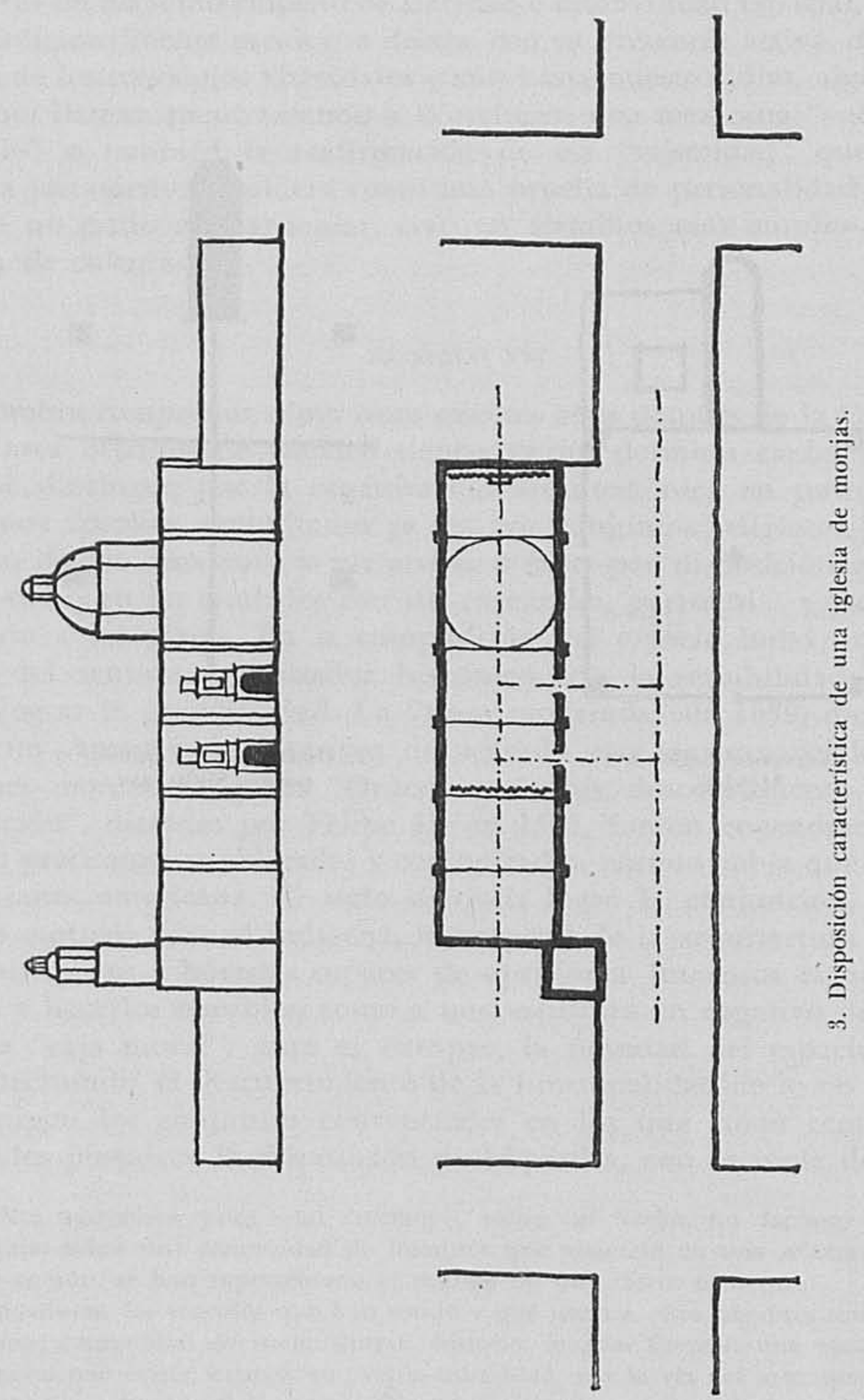


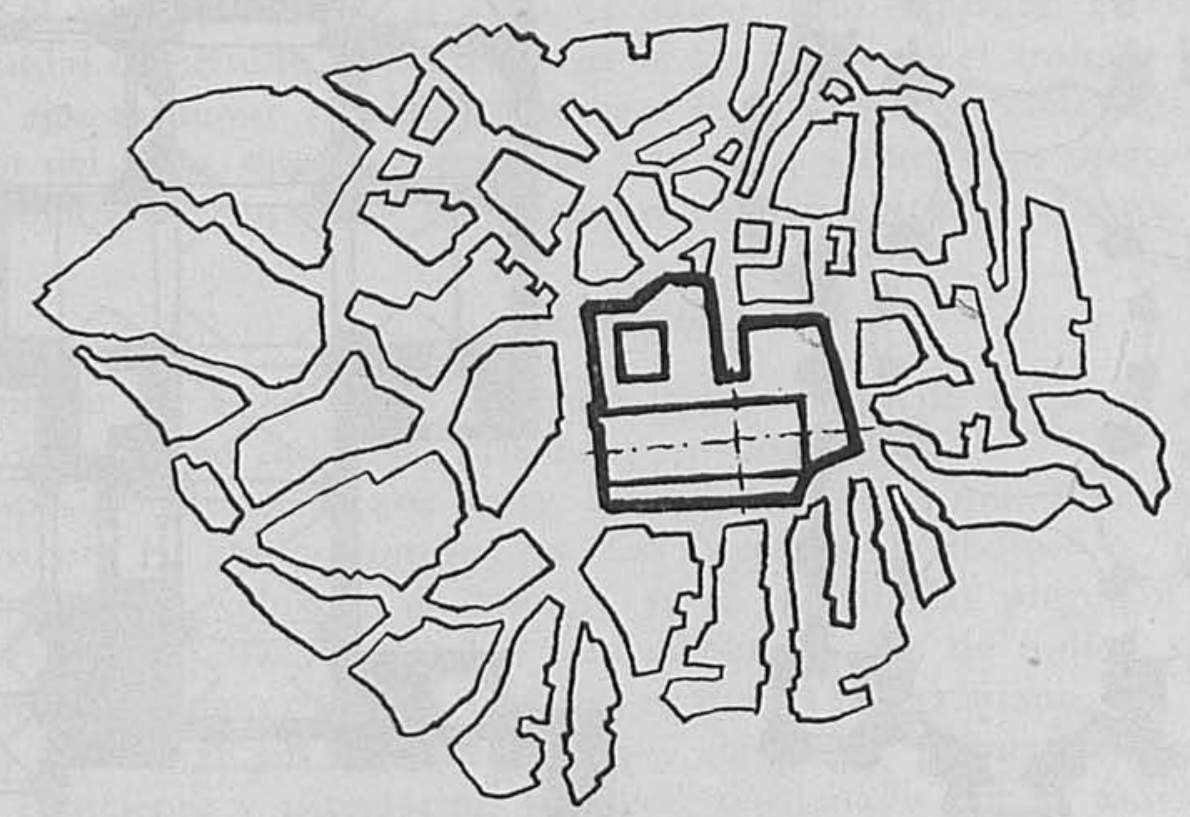

4. Centro de Toledo.
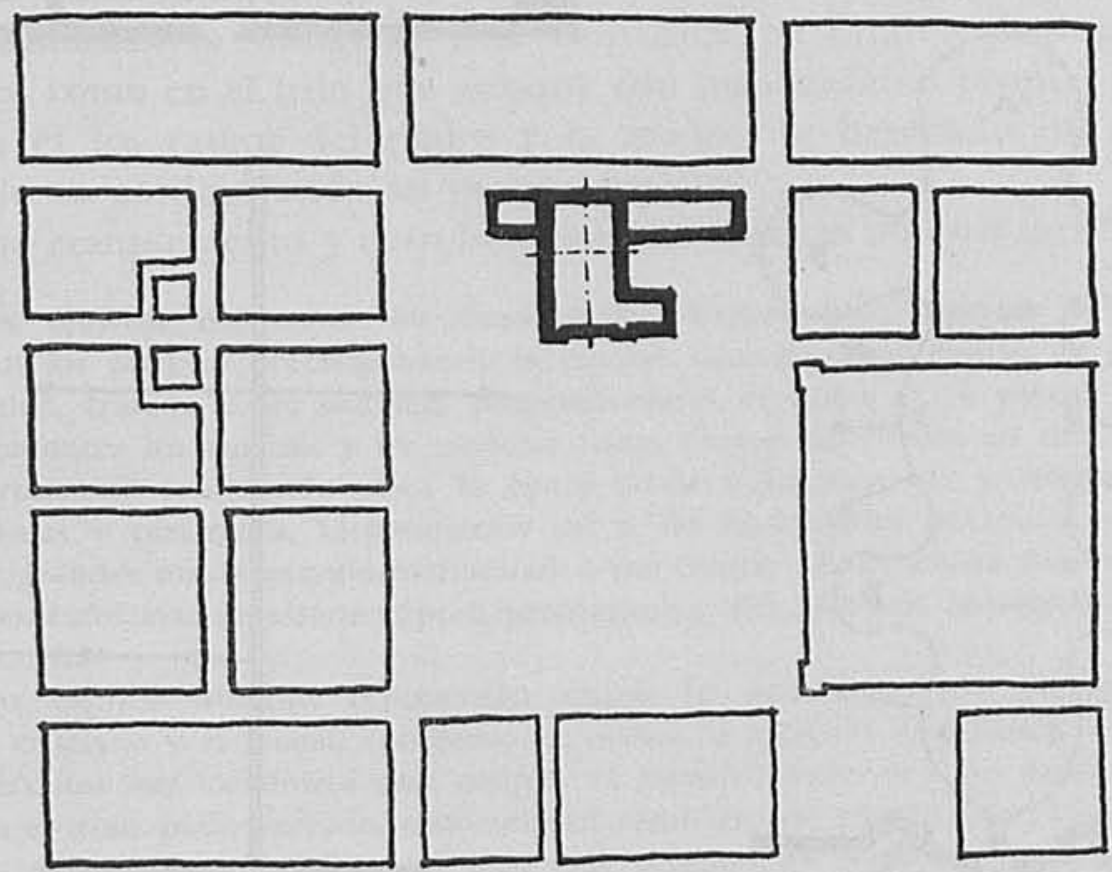

5. Centro de México. 
DOI: http://dx.doi.org/10.22201/iie.18703062e.1966.35.824
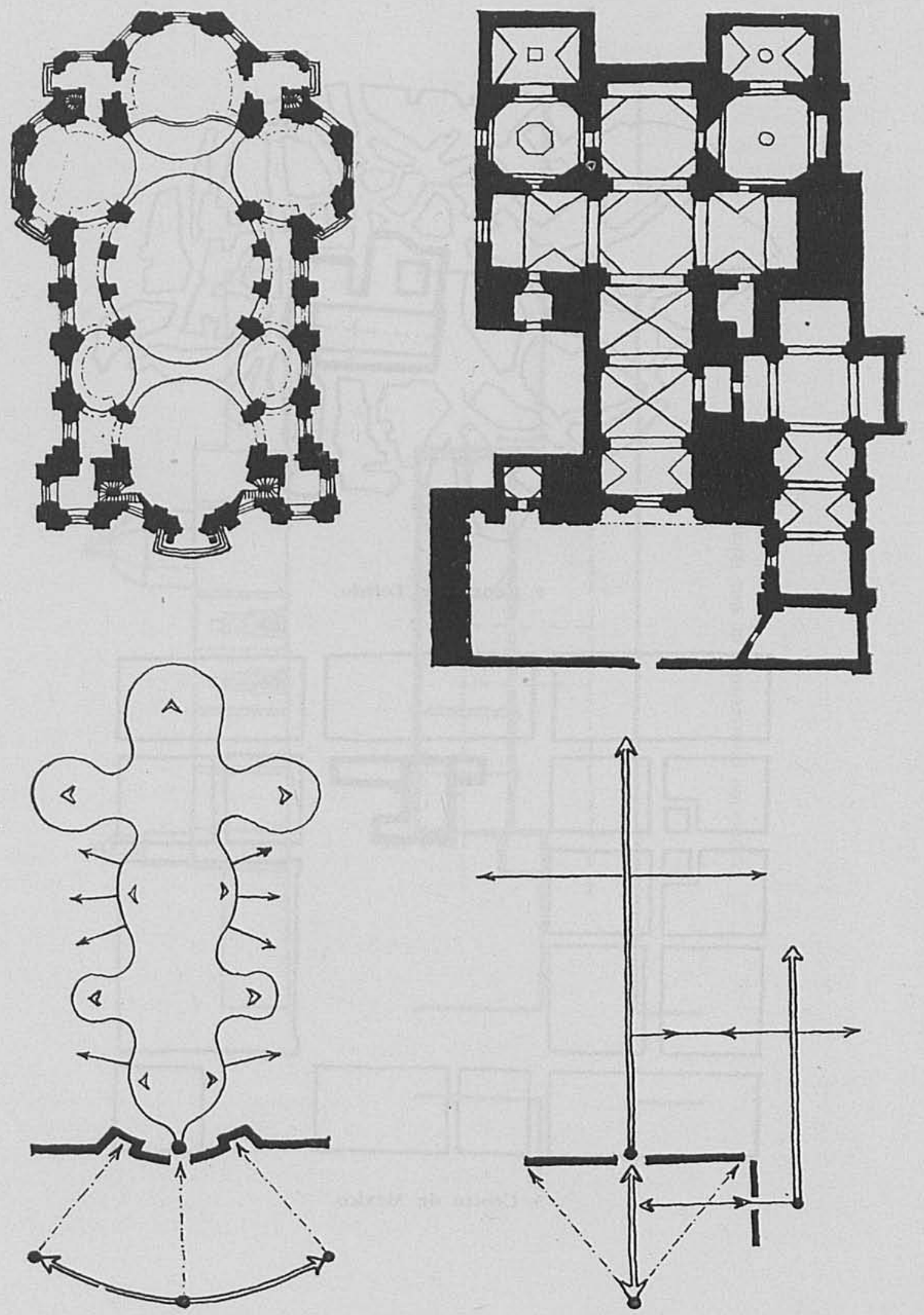

6. Vierzehnheiligen Franconia. Siglo XVIII.

7. Iglesia de San Francisco. Oaxaca. Siglos XVII-XVIII. 
sia y el convento frente al atrio bardeado. Esto equivalia al volumen piramidal construido frente al vacio de las plazas en el antiguo México y los ejes norte-sur y oriente-poniente, se cruzaban precisamente en el centro del atrio, donde se colocaba una cruz, y quedaban marcados regularmente por los vanos de acceso al espacio abierto ${ }^{3}$ (figura 1).

\section{LOS ATRIOS}

Penetrar en estos atrios es sentir cómo surgió de golpe el espacio mexicano, ya no indígena, mas tampoco europeo.

Disposición espacial que surge como respuesta a una función antes inexistente en ambos continentes. Las "capillas de indios" o "capillas abiertas", tan exclusivas de México, ya al nombrarlas pregonan la novedad: son capillas, sí, para el rito católico y son de indios, sí, pero ya para indígenas cristianos. Capillas en que el rito cristiano, con quince siglos de limitar sus recintos sagrados, ahora por primera vez, de manera consciente y sistemática, los abre, presionado por la atávica tradición del rito prehispánico, del culto al aire libre de tradición local. Trasunto de la plaza ritual es el atrio, y del cúe o adoratorio, la capilla abierta. ${ }^{4}$ Este indigenismo se impone y transforma lo europeo, y ambas personalidades, la indigena y la hispánica, se funden distinguiéndose a la vez, como en el hijo que aunque con personalidad propia, permanecen en él los rasgos del padre y la madre, lo heredado de ambos, y con ello va configurando su propio carácter.

Como complemento y corroboración del espacio abierto sacramentado,

3"Los olmecas definieron los lineamientos básicos que, durante veinte siglos, seguirían los pueblos precolombinos: la ciudad sagrada como centro de la vida en comunidad, trazada sobre dos ejes perpendiculares dirigidos a los puntos cardinales: Desde entonces los macizos y los espacios libres fueron ordenados en una disposición que permaneció inalterable hasta la época de la Conquista: las plazas rodeadas dé plataformas y pirámides, respondiendo así a las necesidades del culto espectacular que las grandes masas populares rendian a sus dioses." Raúl Flores Guerrero, Historia general del arte mexicano. Época prehispánica. Ed. Hermes. México-Buenos Aires, 1962, p. 20.

4"Las capillas abiertas representan quizás la única analogía posible entre el templo cristiano y el teocali indigena; en ambos la religión se practica al aire libre; los sacerdotes son los únicos que ocupan el espacio cubierto y los fieles se encuentran en el gran patio cerrado, exactamente como en los adoratorios indigenas. Constituyen, además, estos edificios el tipo más original de arquitectura religiosa en la época colonial, pues que es diverso en su concepción de los que existían en Europa, por ejemplo, las murallas musulmanas." Manuel Toussaint, Arte colonial en México. Universidad Nacional Autónoma de México. México, 1962, p. 13. 
dentro del atrio aparecen las "posas", otra novedad mexicana de este ritual de funciones indoeuropeas; las posas equivalen a los santuarios secundarios que rodeaban las plazas sagradas indígenas $y$, en lo europeo, a las capillas laterales de una catedral cuya techumbre simboliza la bóveda celeste. Ellas también lucen esta abierta intimidad espacial. Su ubicación en los cuatro extremos angulares del atrio hace que delimiten el espacio sagrado y justifiquen su dimensión. Lo delimitan puesto que el culto religioso en su desarrollo espacial, al efectuarse las procesiones, las toca en el tránsito, posando o reposando en ellas. Sus dos arcos en correspondencia con los dos muros ciegos de su fondo, puede decirse que reciben, y limitan, como brazos abiertos, en ángulo, el área del atrio. Las posas son cabezas que vuelven su rostro al centro espacial y sus brazos se prolongan por los pasillos procesionales, que como invisibles naves enlazadas forman asi una especie de girola cuadrada, sensible, aunque no ostensible. Las posas precisan la dimensión del espacio; atrás de ellas está ya lo laico, lo civil, la calle. Si desaparecieran las bardas atriales, que son el límite real del espacio, pero quedaran las posas, el límite virtual de este mismo espacio seguiría sintiéndose y con ellas la funcionalidad de los ejes (figura 2). A la vez, si se dejaran las bardas, pero se movieran las posas restringiendo o ex. pandiendo el rectángulo del atrio que configuran, se sentiría la necesidad de replegar la barda atrial hasta ellas para recuperar el orden de los trazos.

Hay también reciprocidad espacial entre la portada de la iglesia, la capilla abierta y las posas, ya que éstas sin aquéllas no tendrían la jerarquía ni la rígida secuencia entre si, debidas a la procesión que sale de la iglesia y a ella vuelve como origen y meta final. Por otra parte, el espacio vital frente a la capilla abierta se justifica por ella y podría crecer o disminuir arbitrariamente; podría ser caprichosamente elástico sin la presencia de las posas delimitantes. Así ha sucedido en algu. nos conventos en los que destruidas las posas, la referencia desapareció con ellas y el atrio se perdió, quedando la capilla abierta como una cabeza cercenada de su cuerpo al que ya no puede regir. Las capillas posas son los guardianes del espacio que domina la capilla abierta.

Las bardas del atrio también son de lo más significativo en esta organización mexicana del espacio. ${ }^{5}$ Son más estéticas que últiles, sirven

5 "El muro es, en términos generales, la contraparte de la terraza o pavimento y bastan estos dos elementos para postular un sistema arquitectónico. En su forma más simple (es decir, sin la función adicional de sostener el techo) cabe considerar 
más para hacer sensible el espacio que para defenderlo y sus almenas, transportadas de los altos muros, tienen más de rítmica empalizada que de hostil ofensa. Acentúan los límites clarificándolos, pero no asfixiándolos, por eso la barda no necesita una gran altura para conseguir su objeto organizador, aclarador y definidor. Sorprende la escasa altura de estas bardas cuyas almenas son mojoneras de fronteras ideales y un énfasis matemático y rítmico ante los horizontes. Límite vibrante, pero ordenado, pues tras él pueden asomar otras construcciones o la irregularidad del paisaje y por más caóticos que sean los perfiles que haya atrás de la barda, el desorden se detiene ante ellas, porque el espacio del atrio ha quedado sujeto a composición. Lo que está afuera es como un telón de fondo escenográfico en el que las irregularidades ya no pueden destruir la composición segura, quieta y solemne del gran espacio abierto.

En Teotihuacán la "ciudadeja" y la plaza frente a la pirámide de la Luna y en Monte Albán el gran espacio abierto bordeado de edificios, expresan un concepto espacial no lejano de los atrios cristianos, comó pudiera creerse. Quizá subconscientemente, es el antecesor más directo de ellos, y esos espacios tienen también en el centro pequeños altares o adoratorios, como los otros la cruz.

Los atrios cristianos, tan armónicamente configurados, no podían dejar de hacer sensible el punto central de la vastedad de su espacio, punto que siendo equidistante de los principales elementos reuniera en él algo así como los radios de una rueda, las relaciones métricas ahí convergentes. Las grandes cruces marcaban el punto de unión de los dos ejes principales y, desde ellas, el ojo podía girar en torno y apreciar la solemne frontalidad de la portada de la iglesia, las capillas posas, los ingresos al atrio y al interior de la capilla abierta. El ángulo visual se inclinaba necesariamente desde la cruz hasta el altar de la capilla $y$, sobre todo, la vista en perspectiva de las bardas atriales hu-

al muro como una pantalla y, en consecuencia, puede, en conjunción con una superficie pavimentada, proporcionar una definición del espacio. Su característica vertical no sólo sugiere medida, sino que también implica cercamiento, aunque con esta palabra no queremos dar la idea de un área totalmente circundada por paredes. La definición completa, por ejemplo, de un área rectangular mediante cuatro muros adyacentes sólo es un caso especial de la función general del muro, aunque por lo común es este sistema el que se impone a la mente, cuando se utiliza el término "cercamiento". Ya vimos que una superficie horizontal de dimensiones finitas, formalmente determinada, proporciona la base material para una disposición arquitectónica; sin embargo, este elemento - aunque completo en un sentido práctico-- carece del 
yendo hacia los ángulos extremos y siendo recibida y detenida por las capillas posas, que sólo vistas desde la cruz muestran idéntica distorsión en perspectiva al espectador. La cruz es, pues, en estos atrios, el punto de vista más apropiado para gozar y sentir la estática grandiosidad de los espacios abiertos, el orden en la variedad, la armonía entre los volúmenes construidos y los espacios abiertos configurados. Con el șistema logrado, de referencia de este espacio geometrizado y convergente a un centro, era lógico que el efecto plástico espacial pidiera un elemento que sintetizara la razón de ser de todo el conjunto y, así, la consecuencia simbólica es la erección de las cruces tan grandiosas como. el espacio que señalan y a las que el arte esculpió amorosa y primorosamente.

\section{L.AS IGLESIAS}

Si al penetrar en Ios atrios se siente de inmediato la configuración plástica dada al espacio abierto, apenas traspuesto el umbral de las iglesias conventuales del siglo xvi, el contemplador recibe el impacto de la continuidad de los conceptos espaciales ya considerados. En esos interiores son aún más obvios aquellos conceptos, por tratarse de espacios cerrados y perfectamente delimitados. Sus límites son fijos, reales, constituidos por los muros y las bóvedas, que crean volúmenes espaciales àislados. En el exterior la "transparencia" de sus límites virtuales constituida por las bardas atriales permite adivinar el caos fuera de él. En el interior eso ya no sucede y la sensibilidad, al no poder distraerse, es arrebatada y envuelta por el espacio interno que se impone totalmente y hace más ostensibles sus cualidades específicas; el espacio se hace palpable, medible y apreciable.

Absorbidos, pues, nos envuelve tanto el espacio como la caja mural, formamos parte de una escultura vacía, o en negativo. Esta cualidad plástica, absorbente, es exclusiva y distintiva de la arquitectura; todas las demás artes nos dejan físicamente fuera de ellas, sólo la arquitectura es capaz de un apoderamiento tal, de manera que a la sola sensibilidad

componente visualmente necesario para cualquier forma de construcción espacial. Este componente es el muro, el cual, en virtud de su opacidad, obstruye la extensión de la visual mís allá del área que define, y "refleja" de este modo la percepción del espectador (como cabría llamar convenientemente al sujeto que participa de cualquier ordenamiento espacial) y lo retiene dentro de dicho ordenamiento." $\mathbf{R}$. D. Martieassen, La idea del espacio en la arquitectura griega. Ed. Nueva Visión. Buenos Aires, 1958. p. 19. 
le toca saber dejarse llevar por esta sensación, para que después el espectador pueda aprender y dominar la arquitectura con una más cabal apreciación de sus cualidades. ${ }^{\circ}$

Para quien ha penetrado en las grandes iglesias góticas o renacentistas de Europa, que podrían ser comparables por estilo y época a las mexicanas del siglo $\mathrm{xVI}, \mathrm{y}$ ha penetrado también en las grandes naves de Actopan, Huejotzingo (lámina 1), Tepeaca o Cuitzeo, sabe muy bien que hay algo distinto, solemne e impresionante en estas últimas iglesias. Existe en ellas un espacio que no tiene ni la tensión en fuga vertical gótica, ni la precisión hierático-matemática, a veces acompañada de colosalismo aplastante, propia del Renacimiento. Este espacio de las iglesias mexicanas, amplio y alto como el gótico, es un espacio sereno, nítido, en el que todo se abarca de un vistazo. No hay allí las fugas laterales producidas por naves y capillas, no hay tampoco la violenta atracción hacia el fondo, producida por un exceso de longitud acen. tuada por el ritmo de columnas laterales, ni tampoco la presión interna producida por el dominio total de la altura en relación con la anchu. ra. La estructura muestra sus paños verticales constructivos totalmente lisos, y en lo alto se encuentra una noble serenidad en las cubiertas, de grandes cañones corridos o con ricas bóvedas nervadas, o bien ambas se combinan, como es frecuente en estas iglesias y noblemente cierran el espacio a una proporcionada altura. Todo se traduce en un sereno equilibrio de las dimensiones, ni lo ancho, ni lo alto, ni lo profundo prevalecen en demasía; por ello este espacio ni se fuga ni se ahoga y participa tanto de la elevación gótica, como de la razonada elegancia del Renacimiento. Sus grandes proporciones nunca llegan a destruir el sentido de la escala humana, que aquí respira a sus anchas en un tono de sublimación. Es una escala que no se siente aplastada ni envanecida; es un espacio que admira, pero que no arrebata; no hay violencia en él, porque es de una rotundidad antropométrica tal, que sugiere la figura de un torso tranquilo y seguro de sí mismo, que respira serenamente, que se expande y contrae con rítmica vida.

Los muros espesos, lisos y altos, apenas horadados por ventanas que

6"La definición más precisa que se puede dar hoy de la arquitectura, es aquella que tiene en cuenta el espacio interior. La arquitectura bella, será la arquitectura que tiene un espacio interno que nos atrae, nos eleva, nos subyuga espiritualmente; la arquitectura "fea", será aquella que tiene un espacio interno que nos molesta y. nos repele. Pero lo importante es establecer que todo lo que tiene espacio interno, no es arquitectura." Bruno Zev, op. cit., p. 19. 
derraman la suficiente luz, nunca destruyen el dominio de lo masivo; reciben la bóveda que, si es de cañón, se une al muro sin marcar transiciones entre la curva del intradós y la recta del paño sustentante. No hay impostas ni cornisas divisorias, si acaso unas franjas pintadas con grutescos denotan ligeramente esa unión. Así, el espacio no encuentra interrumpidos sus paños límite por ningún elemento volumétrico (lámina 2).

Cuando se trata de las bóvedas nervadas, tampoco éstas interrumpen la planimetría de los muros, y la conjunción de sus nervios y plementos se queda en lo alto, absorbida en ménsulas. Estas bóvedas son como solemnes paraguas en suspensión, en las que los esfuerzos estructurales parecen perderse en su reciprocidad y no transmitirse a columnas o apoyos aislados; por el contrario, se funden en la seguridad del apoyo continuo que ofrece el muro corrido. Aquí también el espacio no sufre tensiones dinámicas y salvaguarda su serenidad de tal manera que las bóvedas de nervadura en México, pese a sus diseños tan ricos y a veces más que muchas de las grandes catedrales góticas, no producen la peculiar sensación de esqueleto activo, propia de la verdadera arquitectura ojival. Lo ascendente y lo descendente no es característico de estas bóvedas; ellas simplemente están. Lucen con mayor abundancia en los ábsides y así es aún más sensible la armonía espacial, que logra que ia profundidad no sea sino el enlace de la anchura y la altura; la nitidez tridimensional se acusa al fondo, como en descansada meta (lámina 3).

Estos ábsides tampoco tienen nada de la calada transparencia del deambulatorio gótico, o del remolino de la girola. Sólo son nichos colosales para alojar la cabeza esculpida de este espacio interior. Es tal la compacta unidad del espacio en estas iglesias, sin protuberancias producidas por capillas cruceros o cúpulas, que siendo necesario dar jerarquía simbólica al presbiterio, al sancta sanctorum, lógicamente apareció la presencia sistemática y típicamente mexicana del arco triunfal. Suave anillo, perfil que denota como índice marcador el tramo más sagrado de esta compacta unidad interior y la distingue de la nave.

Exagerando la imagen, el conjunto del atrio y la iglesia nos sugiere un cuerpo humano en cruz. Si la licencia simbólica va más allá y nos es permitida, creerfamos ver en esto una especie de expresión arquitectónica del cuerpo místico de Cristo, es decir, los distintos miembros de la iglesia configurando un todo. En esa unidad los miembros arquitectónicos no pueden sobrevivir fuera de ella y si bien tienen individualidad, no alcanzan autonomía absoluta, pues aislados perderían su sentido. 
Cabe ahura preguntar nasta que grado es verdaderamente original de México este tratamiento de la composición espacial y cuáles podrían ser sus antecedentes más inmediatos, ya que nada surge por generación espontánea. La pregunta ha sido ya planteada por George Kubler, pero es difícil encontrar la cumplida respuesta. 7 Queda en claro que: "El estilo mexicano de las iglesias de una sola nave progresa más allá de sus antecedentes peninsulares en la unificación y clarificación, no sólo de la planta, sino de las masas y el volumen", esto es, de los espacios. Ese progreso o novedad de matiz mexicano al no tener claros antecedentes europeos debe tenerlos en la tradición local, de manera que, algo del sentimiento plástico prehispánico sobrevivió y se infiltró y mezcló con factores constitutivos del momento histórico, como son lo económico, lo social, lo ideológico, etcétera. De esa mezcla surgió la nueva sustancia: lo mexicano, de la necesidad imperiosa de responder con sinceridad y llaneza lógica a estas nuevas necesidades económicas, políticas y religiosas de la circunstancia histórica local. Ésta hizo que los frailes y alarifes hispanos se adaptaran y dieran solución a funciones que no podían conocer en Europa y, a su vez, que el indígena pusiera esfuerzo, mano de obra y sensibilidad a programas arquitectónicos para él totalmente nuevos. No resulta extraño que esta recíproca entrega e intercambio produjera la originalidad mexicana.

En todo caso, la lección artística aportada por los conjuntos conven. tuales del siglo xvi novohispano, fue de una efectividad y de un arraigo tal en el gusto de la nueva sociedad aquí nacida y configurada, que su sentimiento plástico espacial habrá de prevalecer en siglos siguientes, resistiendo el influjo europeo, absorbiéndolo y transformándolo a la medida de sus intereses. En el transcurrir de los años el rico venero

7 "En ninguna de estas iglesias, sin embargo, de Mondujar o Trujillo o la Magda. lena en Valladolid, nos encontramos la ligera fortificación, con apariencia de castillo, de los ejemplos mexicanos. Los usuales techos de baja pendiente y gabletes, son desconocidos o extrafios al patrón mexicano. Los ejemplares españoles producen sólo un plan básico, con el cual estamos familiarizados en México, en un diseño confuso y con frecuencia oscuro. El estilo mexicano de las iglesias de una sola nave, progresa más allá de sus antecedentes peninsulares en la unificación y clasificación, no sólo ce la planta, sino de las masas y volumen. Las obras de Lorenzo Vázquez, Rodrigo Gil de Ontañón y Francisco Becerra, solas, son inadecuadas para considerarlas en relación con la fórmula mexicana. ¿De qué fuente, sin embargo, derivaron esos artistas españoles la planta de una cola nave? No es nativa de España, Si estos hombres hubieran permanecido del todo dentro de las modas peninsulares, hubieran desarrollado la planta criptocolateral que es normal al gótico catalán, y sin duda, a toda España en la época de los Reyes Católicos. 
europeo sirve de incentivo a la no menos rica imaginación americana y así en el arte barroco encontrará, como dice el mismo Kubler, su "idioma por excelencia". El barroco mexicano aprovecha la lección del siglo xvi, que persevera en la configuración de espacios, cuyas características serán en adelante: composición sujeta a ejes centrados y rectilíneos, límites definidos, nitidez dimensional y una ordenada y solemne quietud. Dejamos por ahora de lado el análisis de otras obras y de un rico tema como el del urbanismo, donde se pueden también encontrar rasgos peculiares, que merece consideración aparte.

En el siglo xvir, el programa constructivo monástico va cediendo el sitio al clero secular. La población va polarizándose en las ciudades de mayor importancia; capitales de provincia en lo civil, sedes episcopales en lo eclesiástico o centros de industria y comercio en lo económico; pero, es más, todos estos factores a la vez se unen en centros urbanos que vendrán a ser las capitales de intendencia en el siglo siguiente, o de Estados a partir del siglo xIx.

Los grandes conjuntos conventuales del xvi quedan, sin mayor desenvolvimiento, señoreando pequeños poblados que se cobijan y adormecen a su sombra. Pero su lección artística no se perderá y así como en ellos se fundieron tradiciones plásticas para formar algo nuevo, a su vez transmitirán un sentimiento plástico propio que servirá de herencia, aprovechada y enriquecida por el estilo barroco, que habrá de colmar las dos centurias siguientes.

\section{IGLESIAS DE CONVENTOS DE MONJAS}

Los conceptos de claridad espacial y rigidez de las plantas se continuaron en cl siglo xvir por una voluntad compositiva y necesidad didáctica, cuya efectividad se habia probado en el siglo xvi.

Desde luego, Rodrigo Gil de Ontañón y Lázaro de Velazco, describieron la planta de una sola nave como muy útil para edificios de tamaño mediano. En efecto, los Gerónimos utilizaron esa planta para sus fundaciones secundarias. Pero el hecho de que una nueva planta encuentre uso, no cuenta para sus orígenes.

Hemos ya sugerido en alguna parte de este volumen, la posibilidad de asociar Ios ejemplares hispano-mexicanos con las iglesias de una sola nave del siglo xul del suroeste francés. El emplazamiento, planta, estructura, masas, volumen y efecto visual de los dos tipos, todo justifica la asociación. La tesis ha sido discutida, pero permanece el hecho de que la reconcentración franciscana en los años de 1530 a 1540 era en el sur de Francia y de que muchos frailes franceses vinieron a México.

Por el mómento la hipótesis debe dejarse sin mayor argumentación; péro no debe ser descartada." George Kubler, Mexican Architecture of the sixteenth century. New 

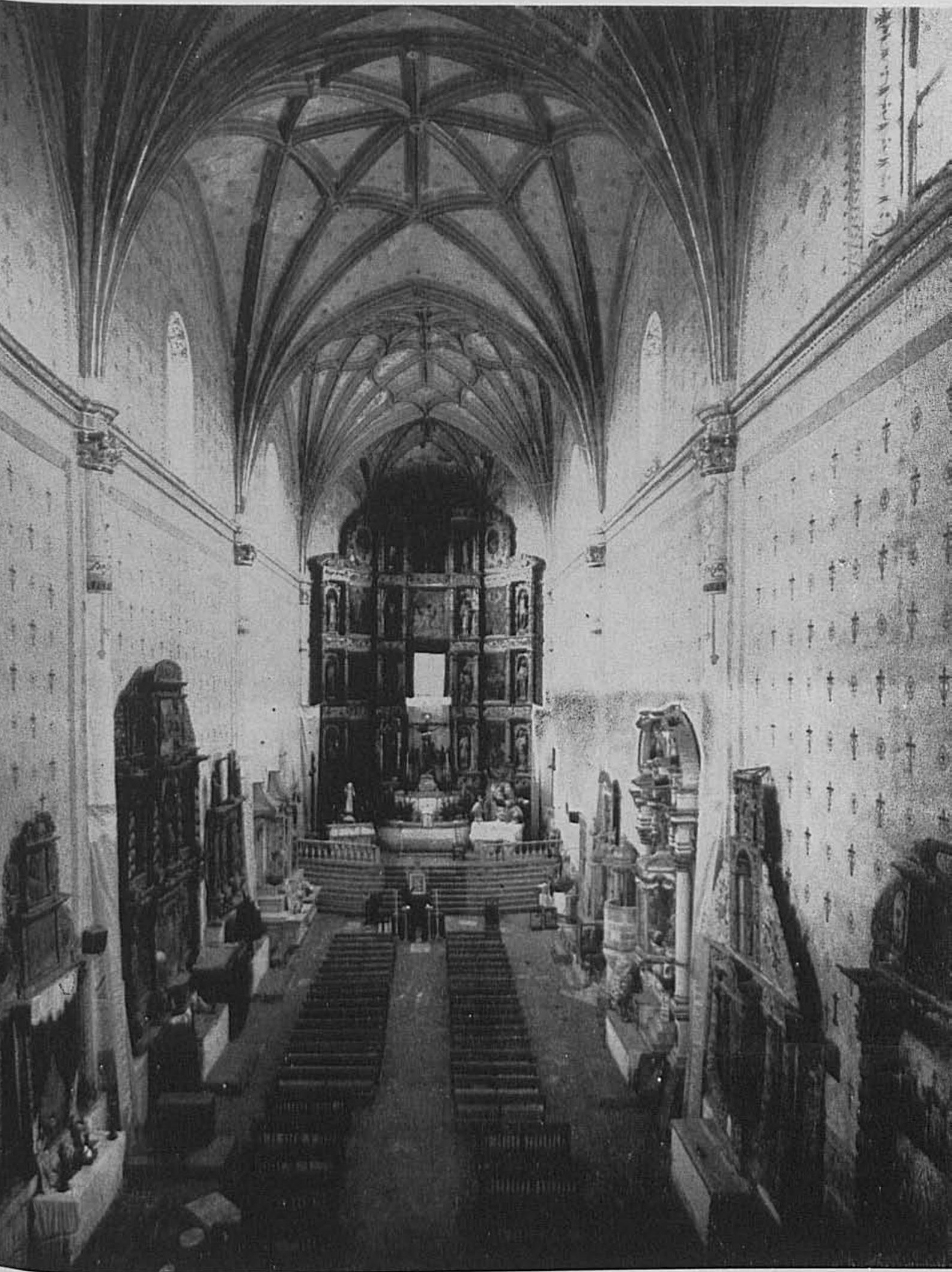


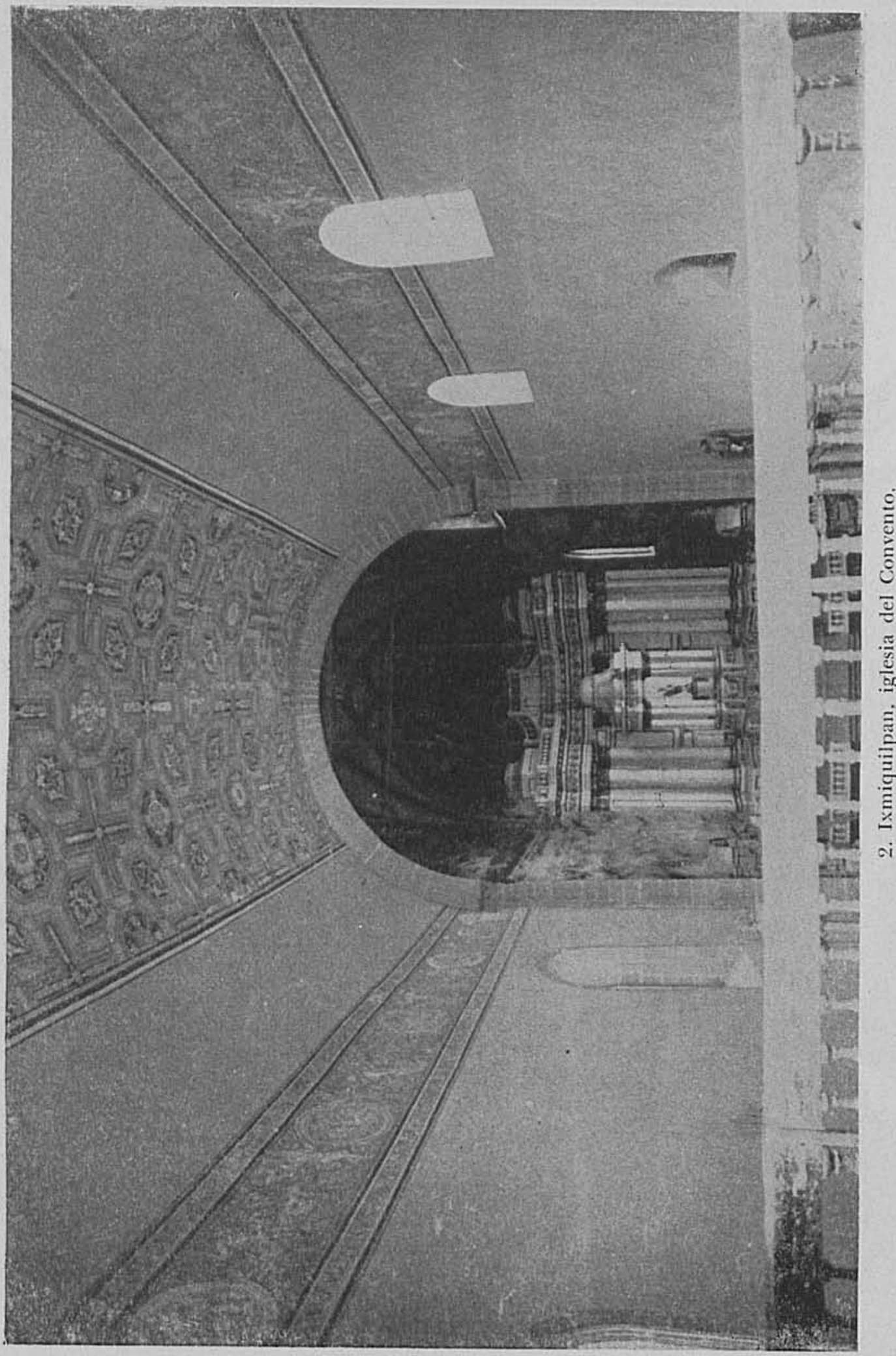




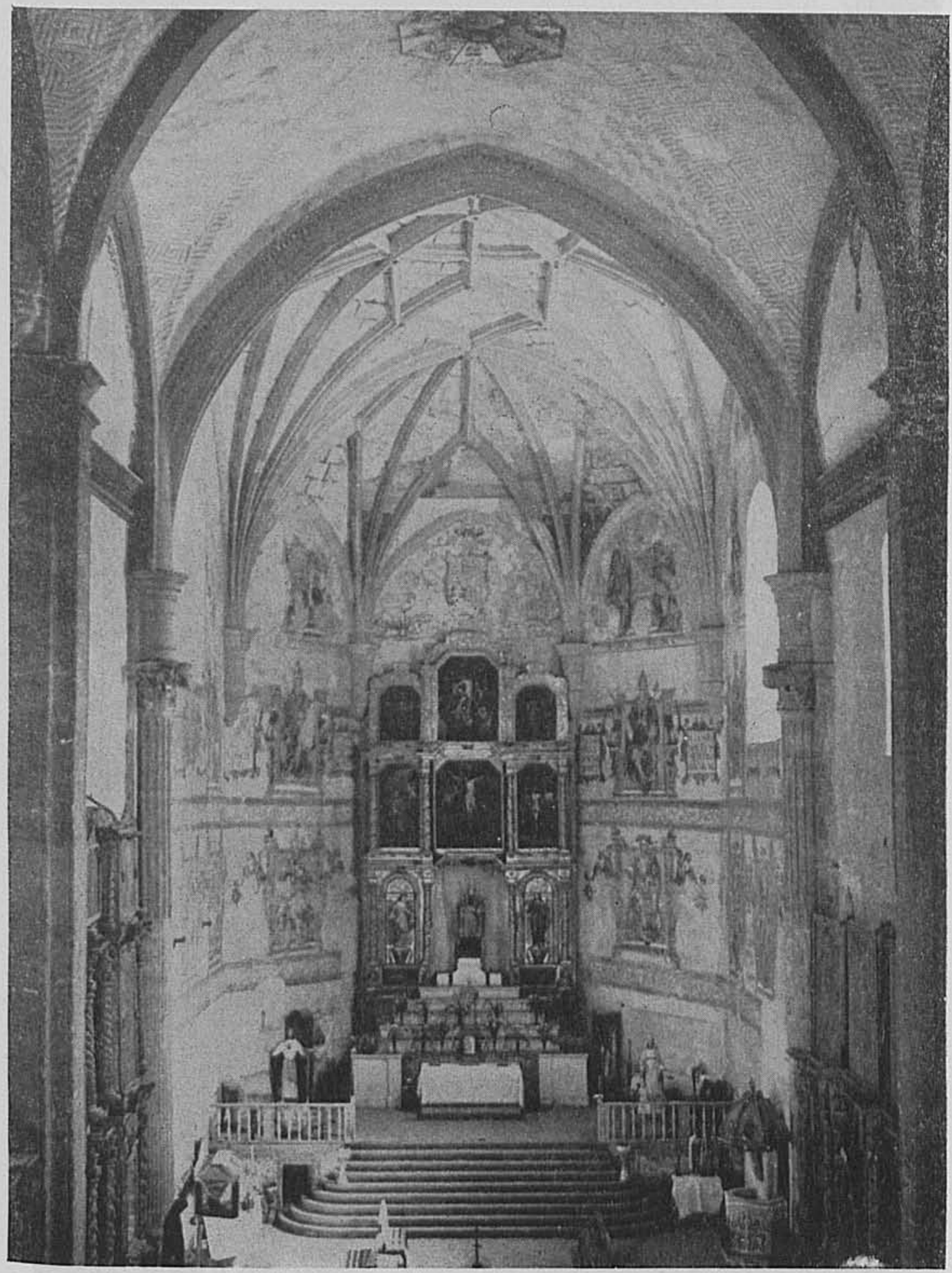

3. Acolman, ábside de la iglesia conventual. 
DOI: http://dx.doi.org/10.22201/iie.18703062e.1966.35.824

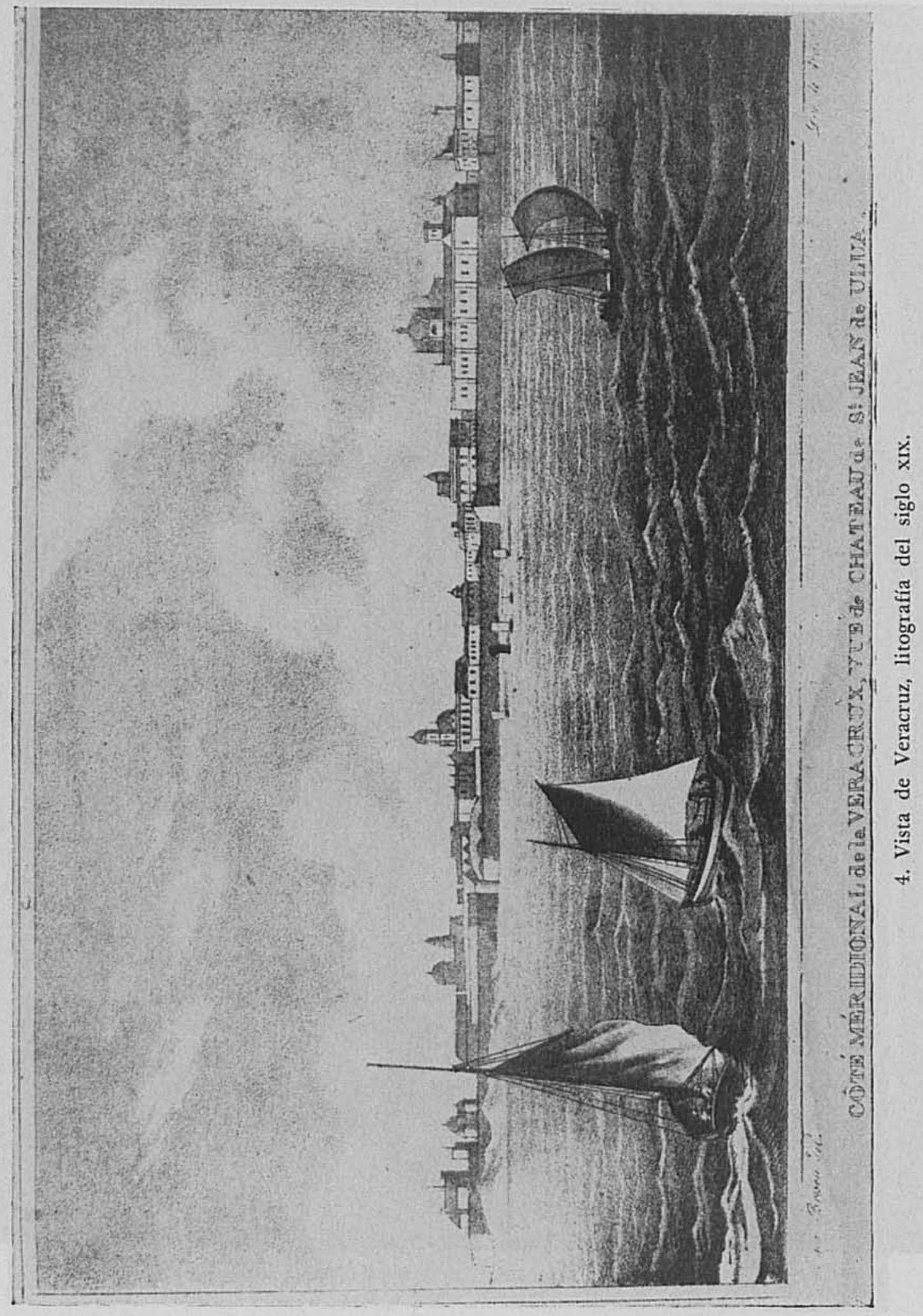



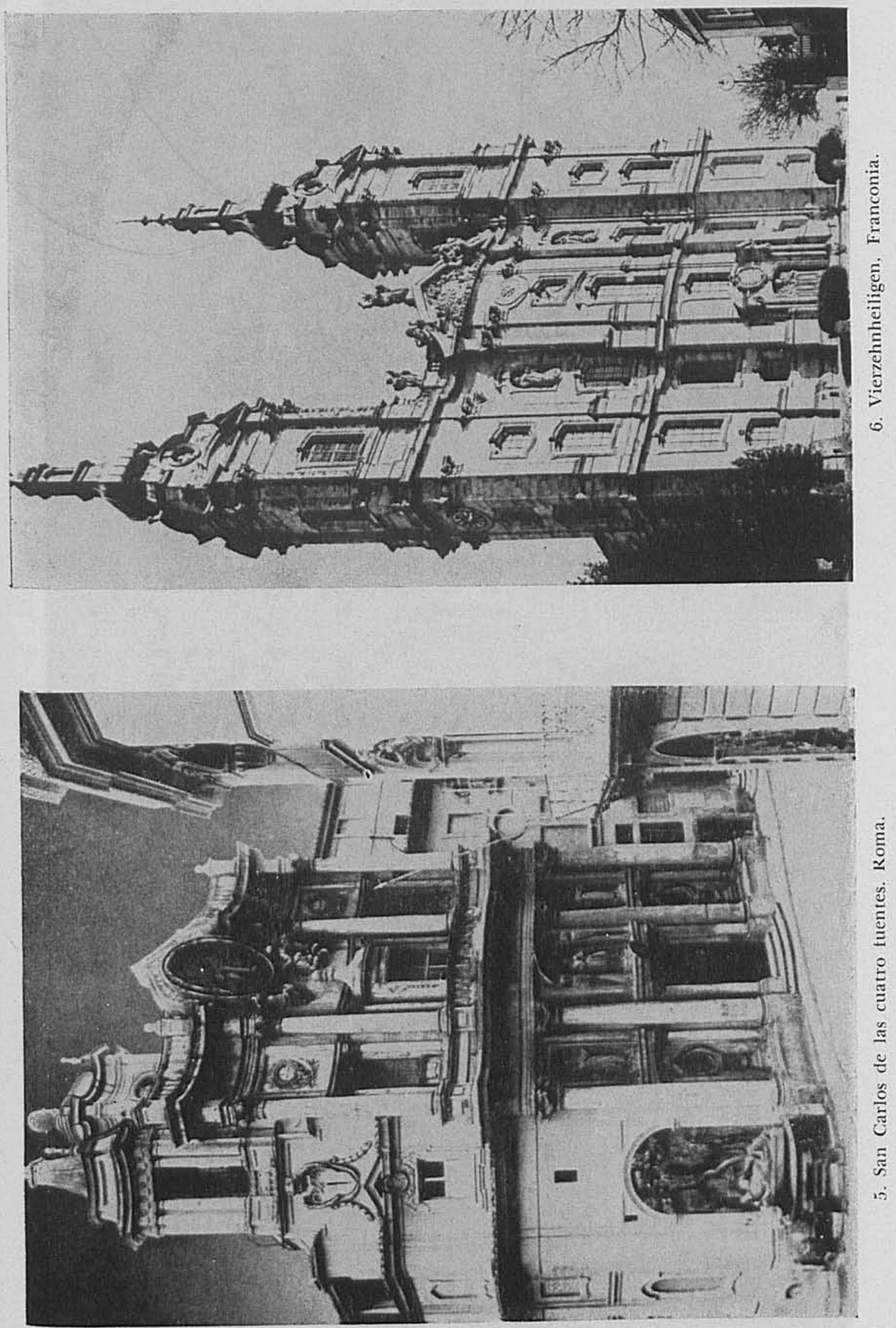
DOI: http://dx.doi.org/10.22201/iie.18703062e.1966.35.824

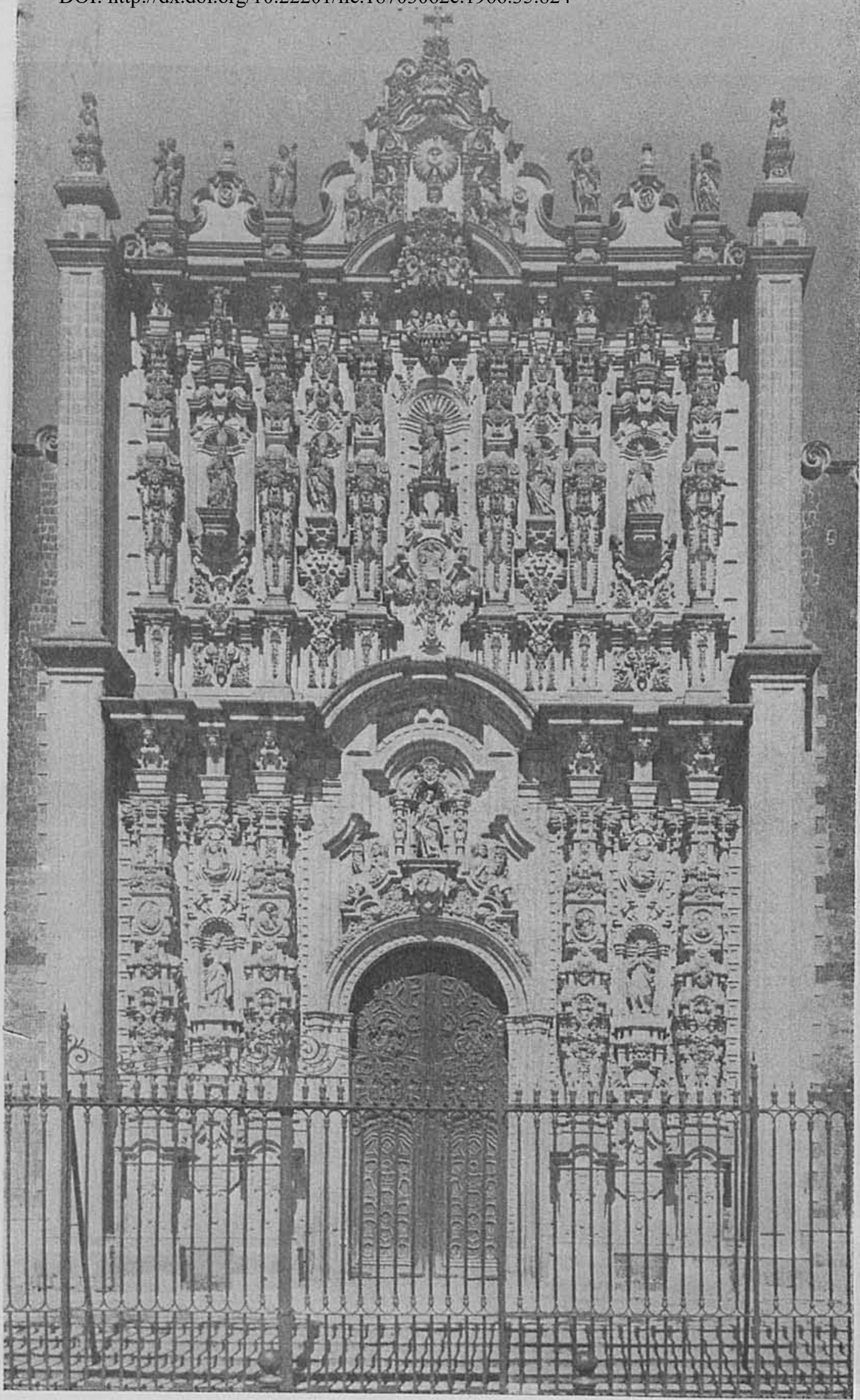




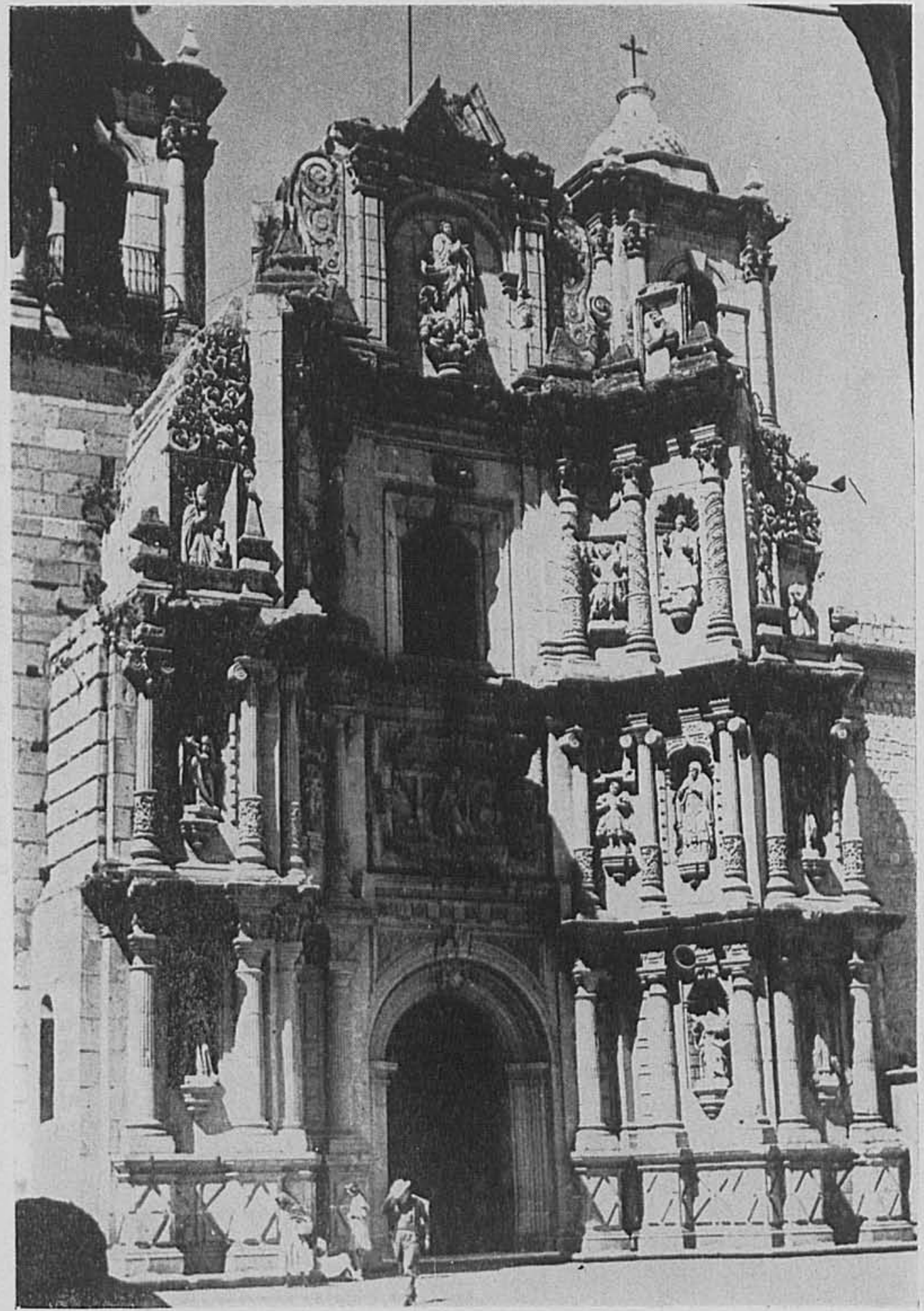

8. Iglesia de la Soledad, Oaxaca. 
DOI: http://dx.doi.org/10.22201/iie.18703062e.1966.35.824

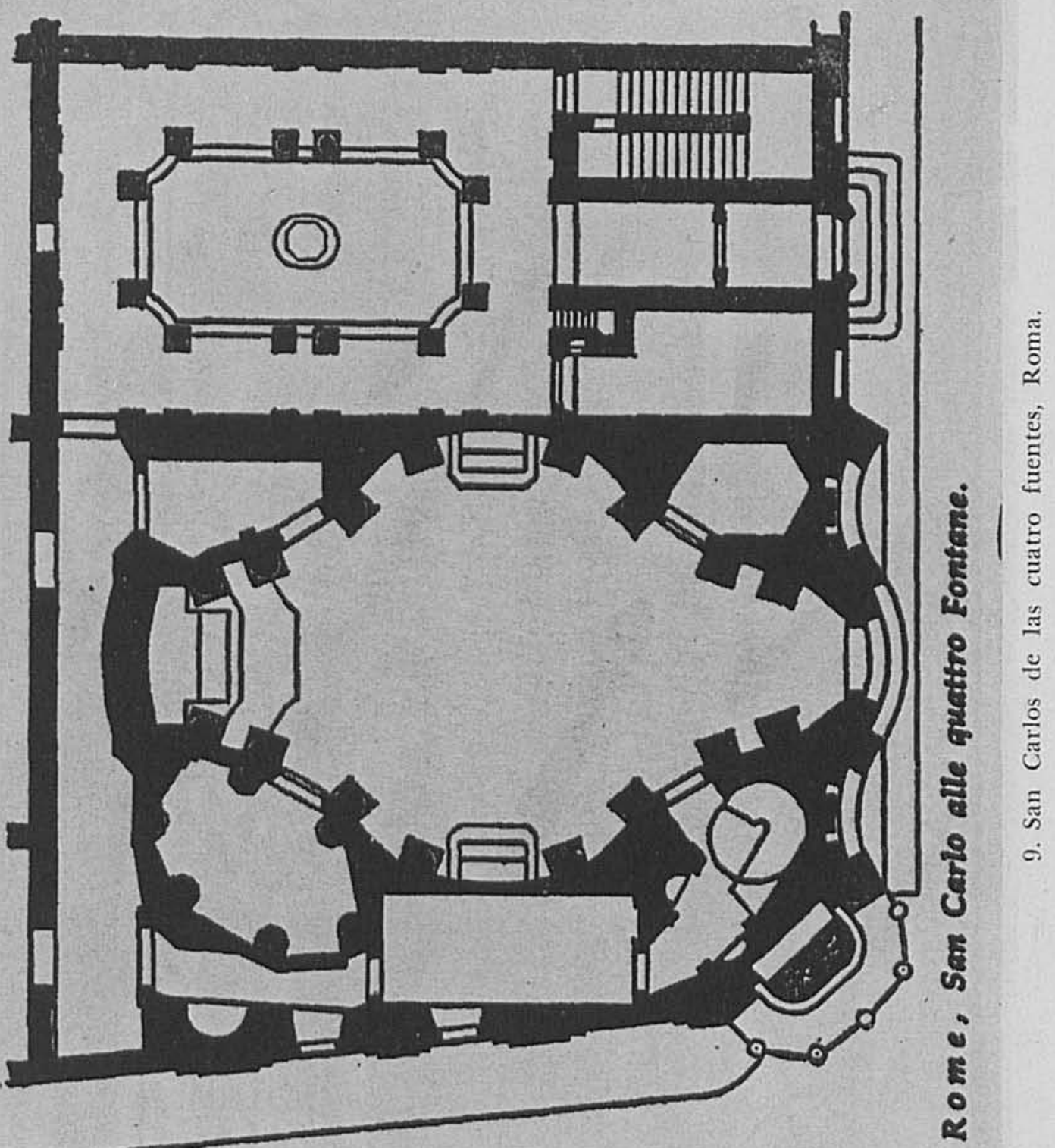


DOI: http://dx.doi.org/10.22201/iie.18703062e.1966.35.824

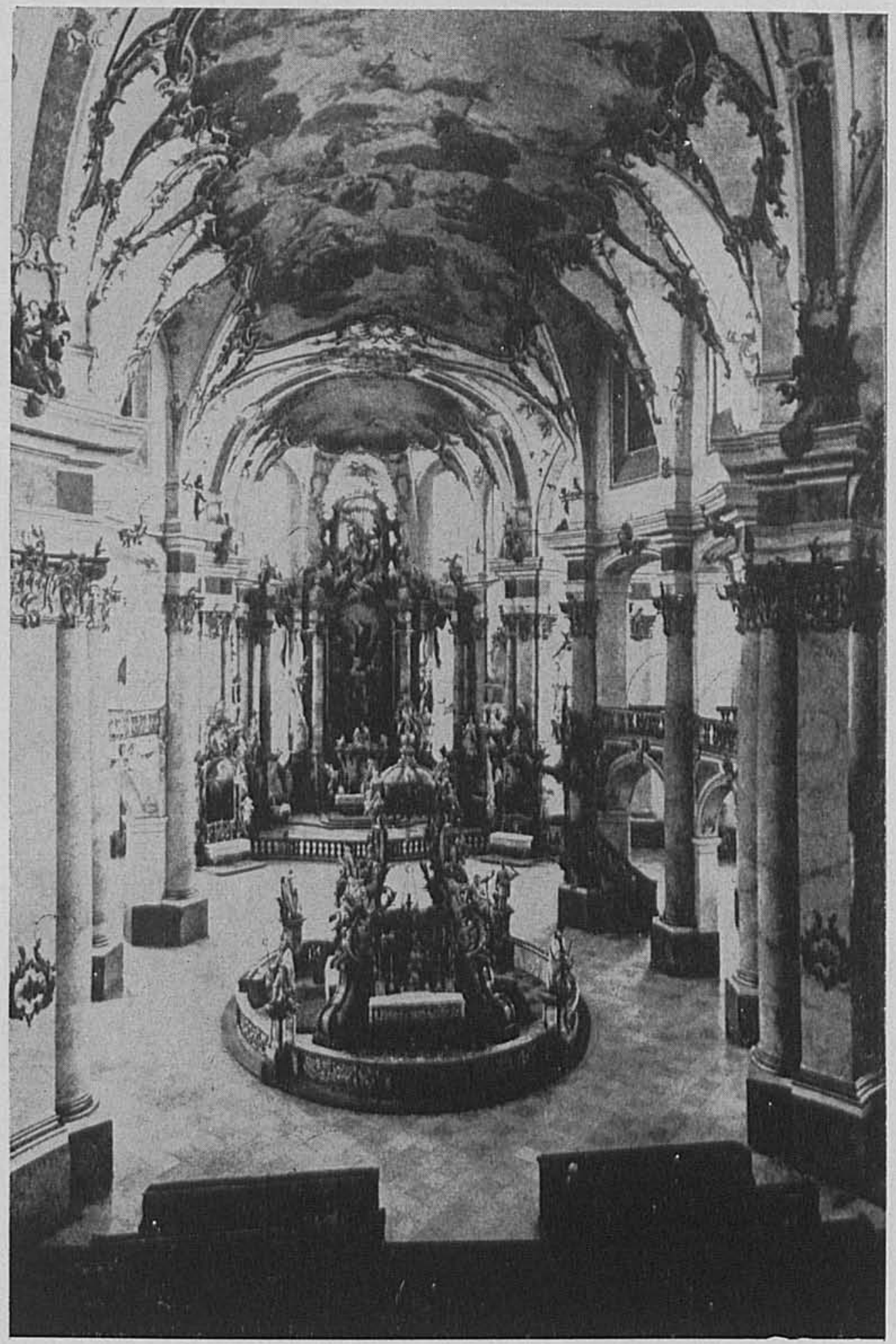

10. Iglesia de los catorce Santos, Franconia. 


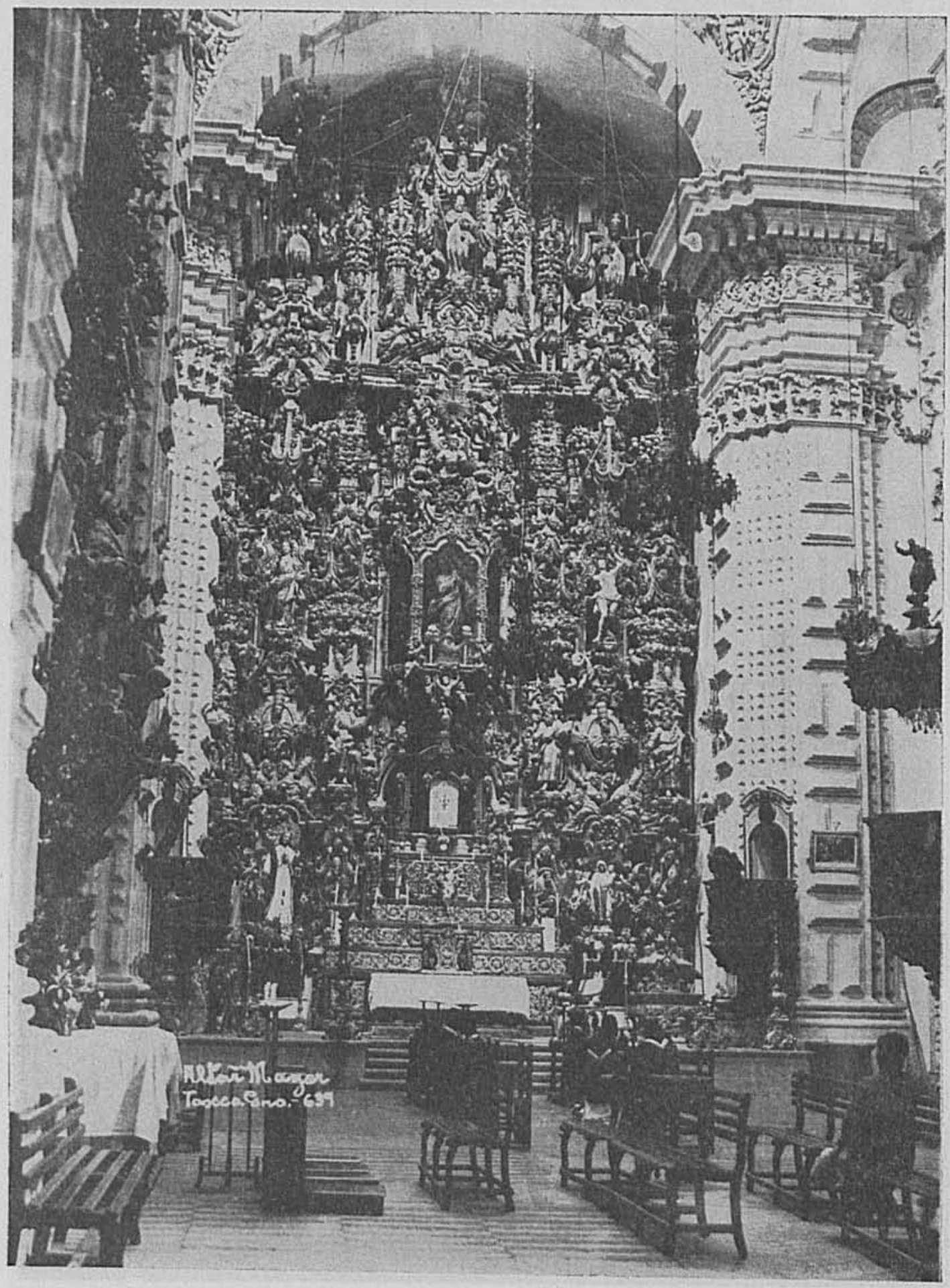

11. Retablo Mayor de Santa Prisca, Taxco. 


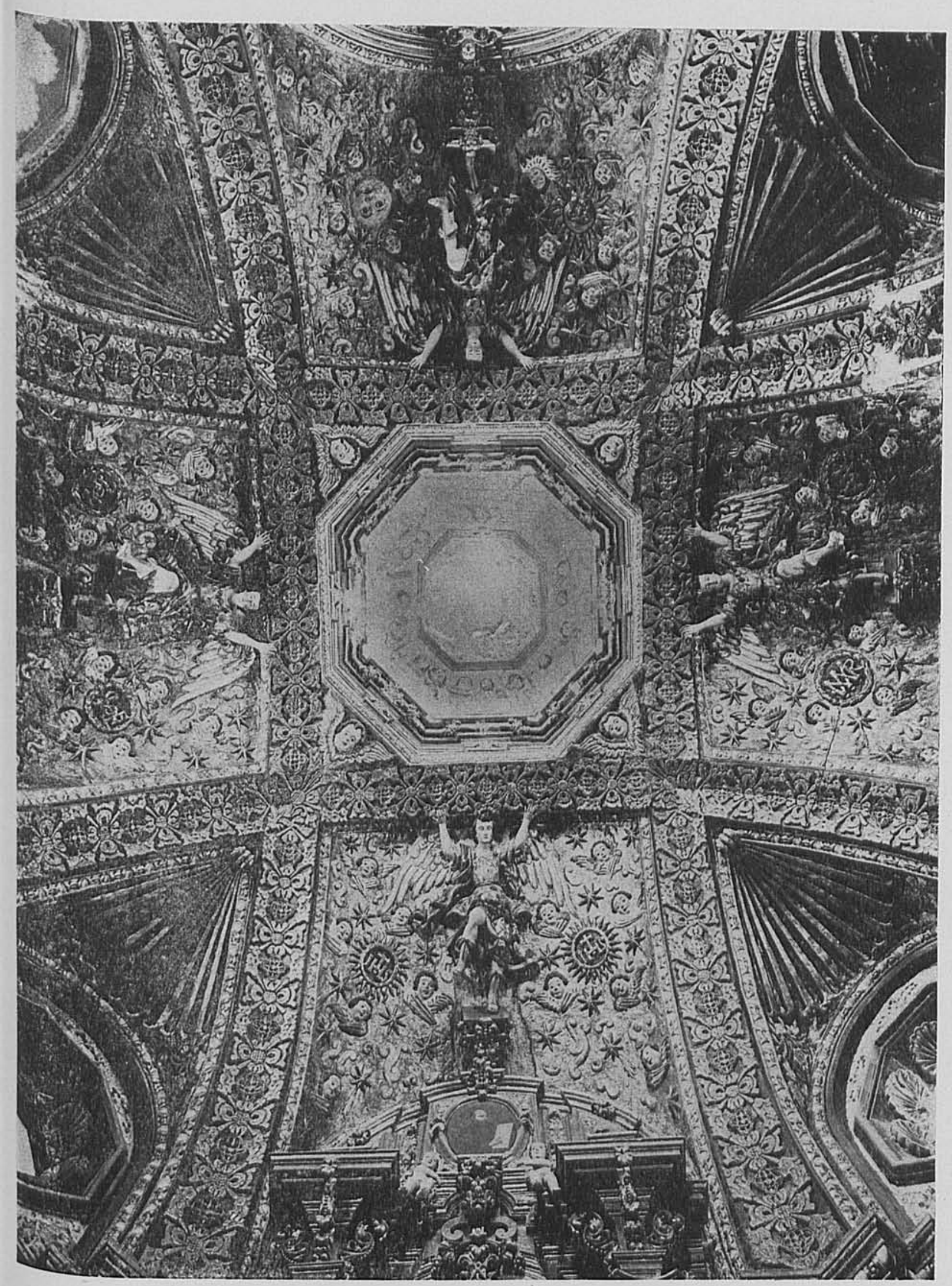


DOI: http://dx.doi.org/10.22201/iie.18703062e.1966.35.824

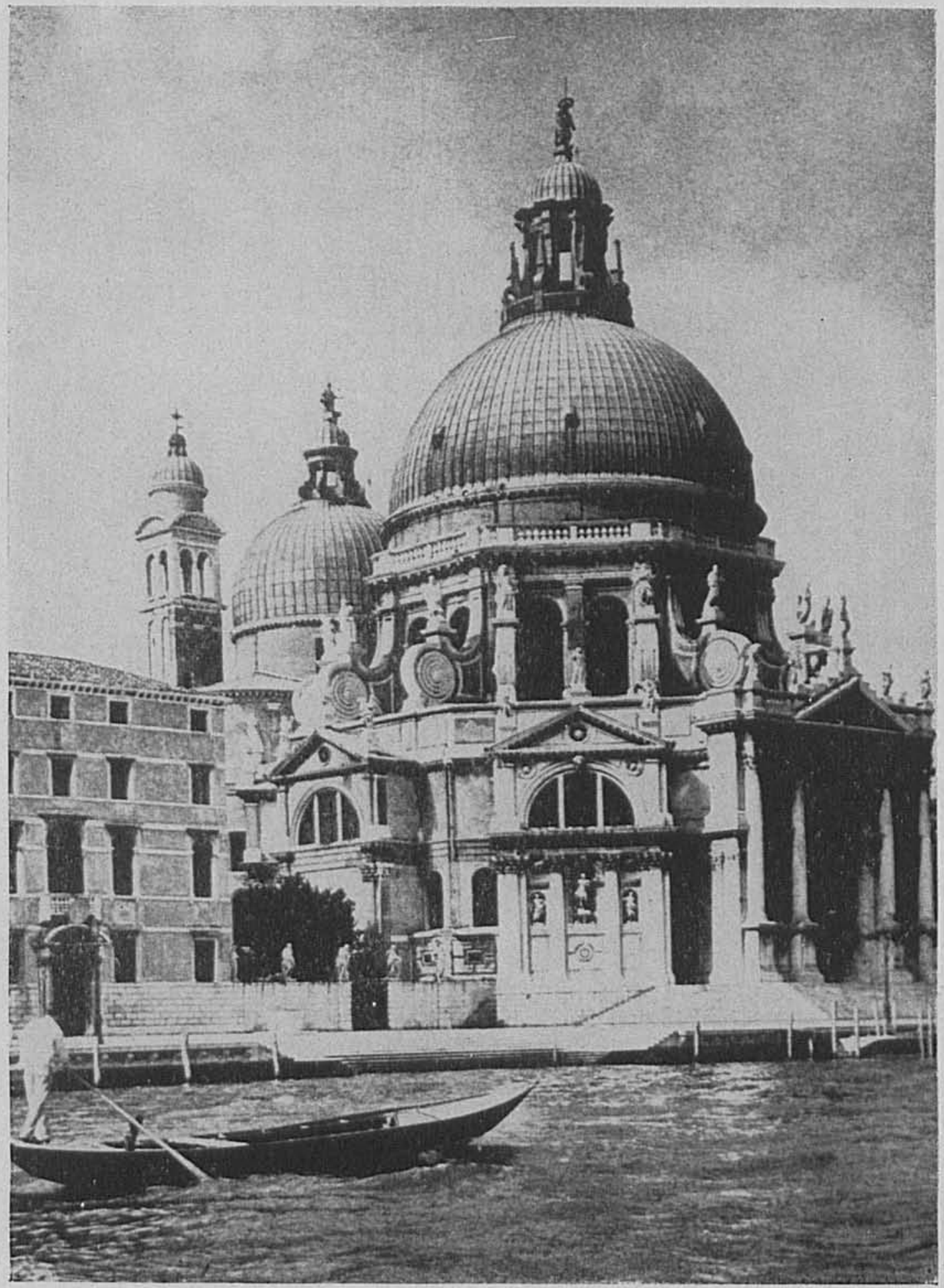

13. Iglesia de la Salud, Venecia. 
DOI: http://dx.doi.org/10.22201/iie.18703062e.1966.35.824

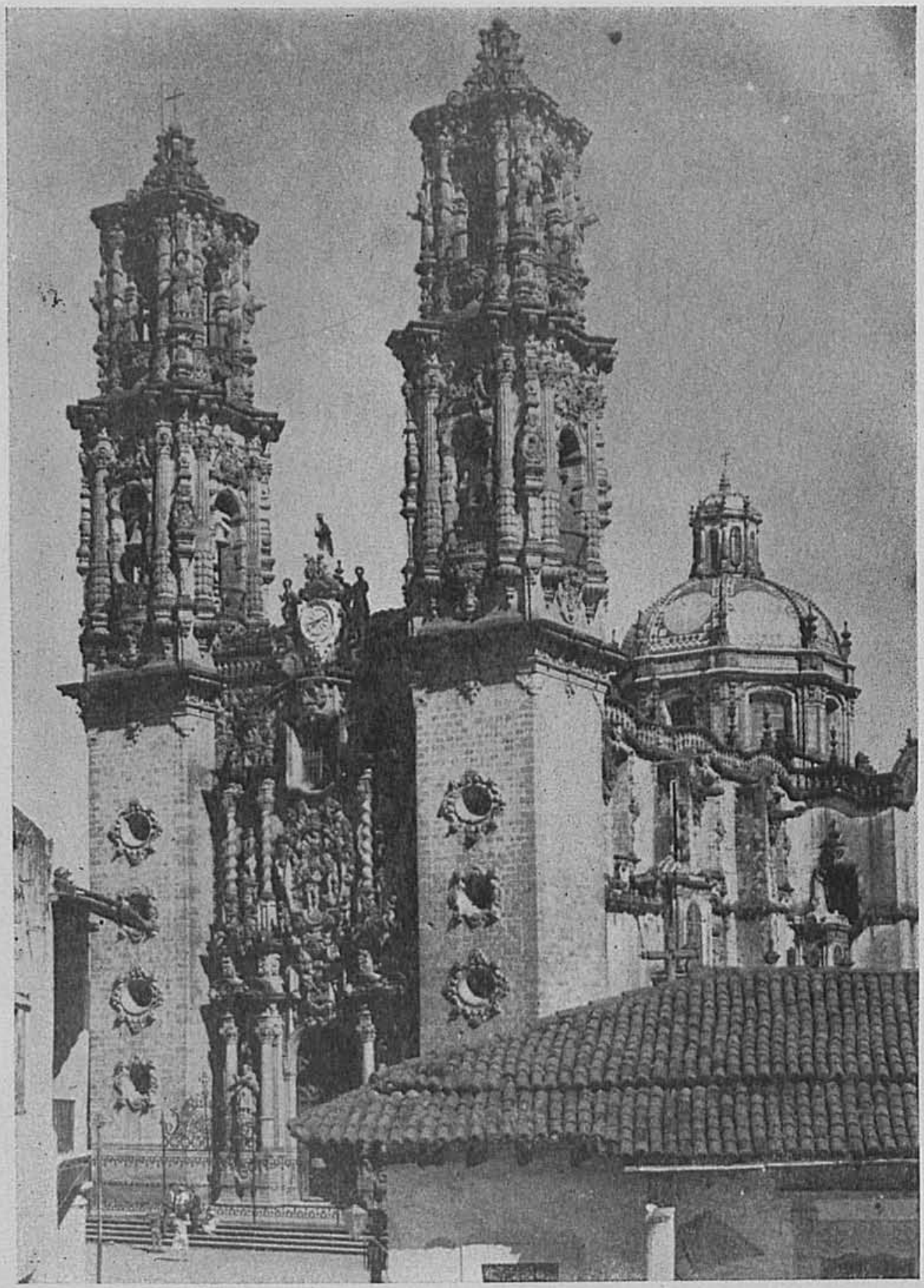

14. Conjunto exterior de Santa Prisca, Taxco. 


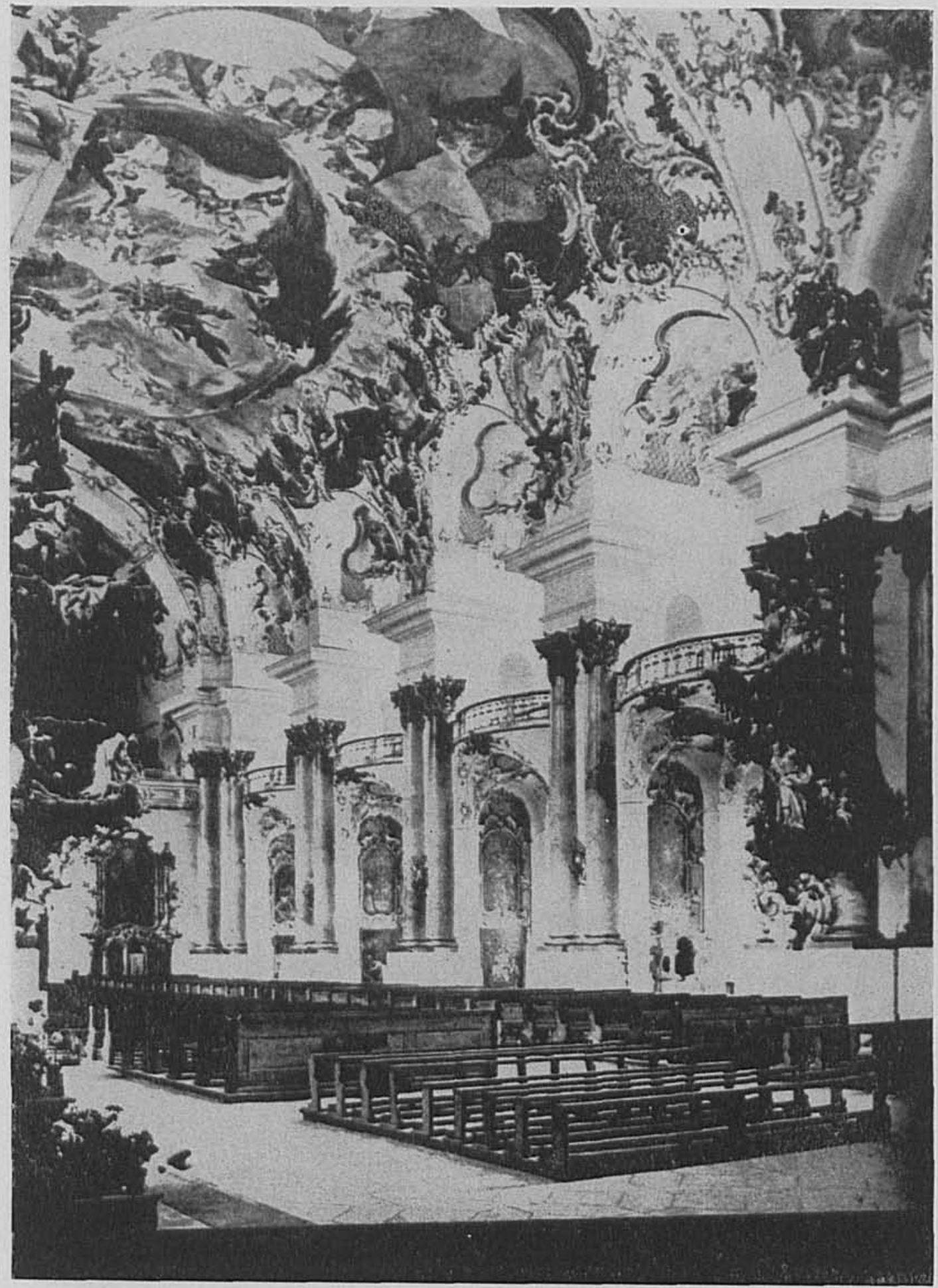

15. Iglesia del Convento de Ottobeuren, Suabia. 


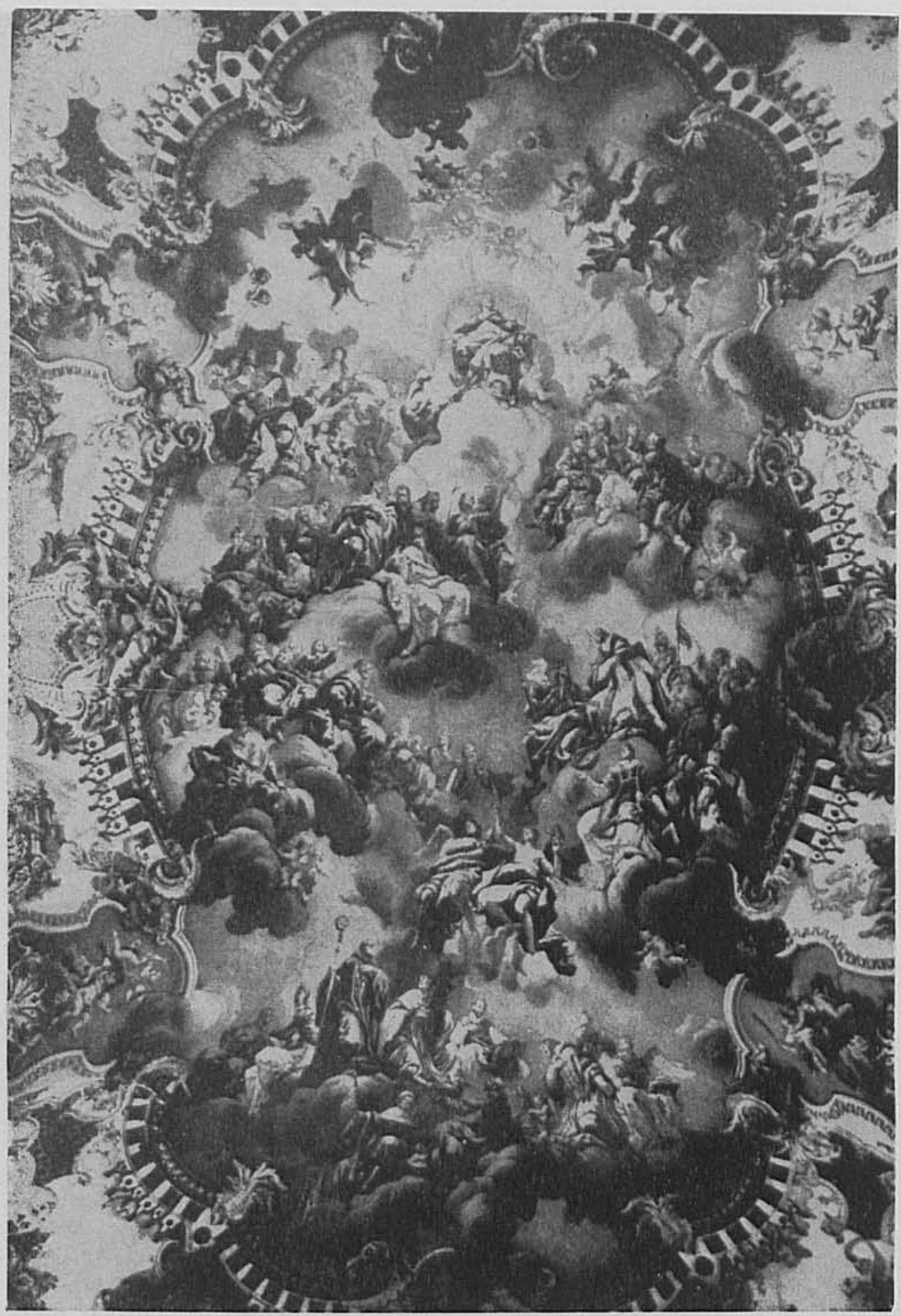

16. Convento de Wilhering, Austria. Fresco en una bóveda representando "El Triunfo de la Iglesia". 
DOI: http://dx.doi.org/10.22201/iie.18703062e.1966.35.824

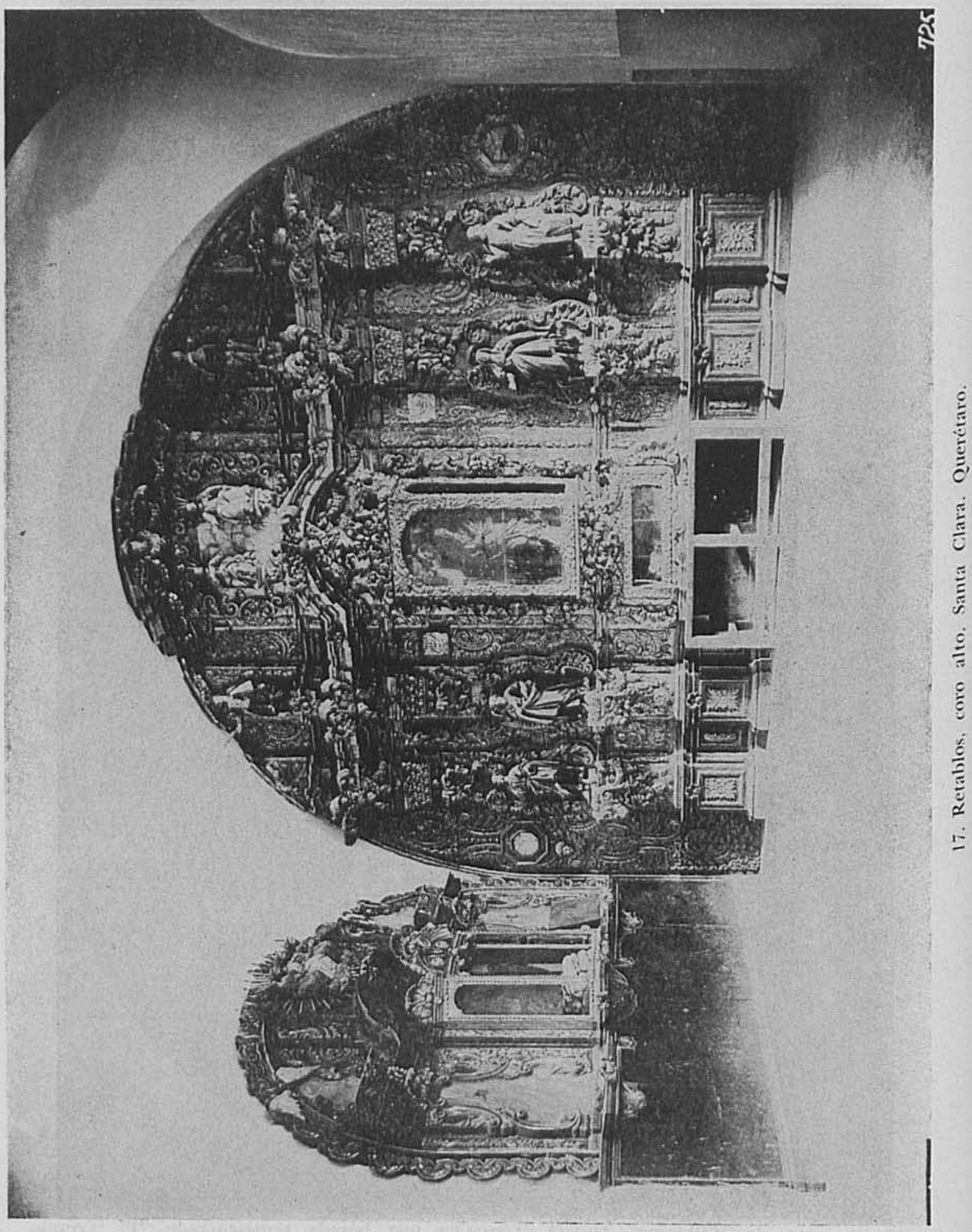


Dos son los más significativos tipos de construcción religiosa en el siglo xvir: las iglesias de conventos de monjas, erigidas para la vida contemplativa bajo la influencia de la pasividad femenina, y las parroquias, destinadas a la vida activa y organizada del clero secular.

Las iglesias de monjas, aunque existentes en todo el mundo hispánico, en México tienen una multiplicidad mayor y aquí también, su progra. ma distributivo es tan perfectamente sistematizado y respetado, que alcanza una fórmula inamovible y categoría arquitectónica. 8

Como en el xvi, los antecedentes europeos de las iglesias de conventos de monjas se pierden y no son suficientes para explicar su distribución espacial, la reiterada y por ello monótona repetición de sus elementos. En estas iglesias es imprescindible la presencia de tres elementos arquitectónicos distintivos: coros unificados, su prolongación en una sola nave, y en un costado el ingreso a través de dos entradas pareadas. En el siglo xvin se añadió otro elemento, muy importante, constituido por la cúpula antepresbiterial.

Por razón de su función ambivalente, ya que estas iglesias mezclan la vida claustral con la pública, la masa del templo es frontera entre el convento monjil propiamente dicho y la calle y su espacio interno

Haven. Yale University Press, 1948, vol. 11, pp. 238-239. (Párrafos traducidos por Elisa Vargas Lugo.) Véase también al respecto el importante libro de John Mc Andrew, The open-air churches of Sixteenth-Century Mexico. Cambridge, Massachussetts. Harvard University Press, 1965.

8 "El templo debía ser público, es decir, abierto al pueblo para que pudiese asistir a todas las ceremonias que en él se celebraban, pero la clausura del convento, que mecluía a las monjas en un mundo aparte, exigía que dicho templo fuese construido en tal forma que, gozando de libre acceso por parte del pueblo, pudiese servir a las monjas, sin que éstas fuesen molestadas en su recogimiento. La solución es perfecta: se edifica un templo de una sola nave para que ocupe menos espacio y su eje principal se traza paralelo a la vía pública, con lo cual se logra darle iluminación perfecta y permitir el libre acceso a los fieles sin molestar en lo minimo a las hijas de Dios que habitan el monasterio. Se desarrolla ampliamente el coro, que a veces se ve casi tan grande como la misma nave, y además, es doble, es decir, uno en la planta baja y otro arriba; el coro bajo está dividido del templo por una reja cuyos hierros presentan hacia afuera picos terribles que parecen simbolizar las garras de un dragón que defendiese a las monjas del peligro exterior; a los lados de esta reja dos ventanillas, las craticulas, que permiten a las monjas recibir la comunión sin que el sacerdote penetre a la clausura; el coro alto no ostenta esa reja formidable, sino otra más sencilla, pero cubierta, como la de abajo con mamparas de tela que permiten ver desde el interıor y no toleran que la mirada del pueblo se dé cuenta de lo que acontece en los coros." Manuel Toussaint, Arte colonial en México. Imprenta Universitaria, 1948, p. 193. 
es el puente de contacto. Así, el juego del espacio interno y del espacio externo obligó a una lógica colocación del templo con respecto a la calle, de manera que, dos grandes ejes paralelos lo definen; uno perteneciente al espacio interior de la iglesia, el otro al eje longitudinal de la calle, pero ambos están centrados y son estáticos en sus fugas por un tercer eje unificador, correspondiente al ingreso. Así tenemos una especie de $\mathrm{H}$, en la que el paralelismo encuentra como punto de reposo el eje transversal, que no por corto deja de ser el más importante y esclarecedor, pues el que fija la conjunción haciendo de la paridad, unidad (figura 3). Es curioso observar cómo en estos templos se logra perfectamente el equilibrio de elementos paralelos, pero distintos, para hacer prevalecer la armonía plástica. El fiel de esta balanza se apoya precisamente en las dos portadas idénticas y juntas a media nave, que se contrapesan haciendo inmóvil el cuerpo de la iglesia; en los extremos, la cúpula por un lado y la torre por el otro, limitan volumétricamente el edificio. Lo que la cúpula podría vencer en densidad de volumen esférico, la torre lo equilibra en volumen cilíndrico; asf quedan fijos y estáticos los volúmenes exteriores y tienen en la fachada su punto de relación y contacto. Toda la estructura corre con la serena fluidez de los vasos comunicantes y la posible fuga de la perspectiva callejera queda casi anulada y antes bien se fija con las portadas pareadas. Volumen construido y volumen abierto, quedan rígidamente sometidos a ordenada relación.

En el interior se prolonga esa unificación de la paridad; son iglesias de una sola nave, sin cruceros, y como se entra a ellas por un costado, el espacio interno se fuga ante el espectador hacia los extremos; sin embargo, es detenido de inmediato por los paños límites, por el testero plano en un lado y por el alzado del coro en el otro, ambos de idéntica dimensión. Sabiamente se echó mano de la decoración para de una sola vez unificar, distinguir y equilibrar estos dos elementos, poniendo el rico retablo en el testero y frente a él, haciéndole juego, la fachada del coro, en composiciones preciosamente ornamentadas. Las rejas, pinturas y tallas cumplen varias funciones, pues si bien embellecen el paño, separan la clausura de lo secular; encierran y funden en una sola compacta unidad el espacio de los coros altos y bajos. Sin las fachadas de los coros la gran masa espacial del interior de la iglesia perdería su clara unidad, viéndose seccionada en uno de sus extremos, pero con ellas el espacio encuentra este tope que lo limita. Lo que llamo "fachada" es una gran mampara, en que la transparencia de las rejas permite 
que el espacio se tamice o filtre tras ella, pero sólo después de haber colmado la caja interior.

El espacio que crean estas iglesias monjiles resulta similar al de los cofres o baúles, con su planta rectangular, sus cuatro paños verticales planos, y su tapa, o sea la comba de las bóvedas; la cerradura o chapa son las portadas pareadas en su costado. En pocos ejemplos es tan claro, como en estas estructuras, la idea de que la arquitectura es la "caja mural" del espacio.

Vale la pena observar cómo en estas iglesias se unifica la paridad, pues la sensación de unidad que producen se basa precisamente en la acertada función de elementos paralelos: dos son los ejes paralelos principales, el de la iglesia y el de la calle, que se funden en la fachada constituida a su vez por dos portadas iguales; dos son los paños principales interiores, el retablo y la fachada coral; y dos son también los coros que se unifican en las rejas donde los dos mundos, el secular y el claustral también se tocan.

\section{IGLESIAS PARROQUIALES}

A partir del siglo xvir, la iglesia parroquial, con su planta en cruz latina, su cúpula en el crucero, sus muros rectilíneos y su fachada y testero planos, es el modelo más abundante y difundido que sirvió de ejemplo dogmático a la arquitectura eclesiástica del virreinato. Es el patrón que resume las lecciones espaciales anteriores y que considerado perfecto en cuanto a símbolo, funcionalidad litúrgica y efectividad plás. tica, ya no interesó renovar, antes por el contrario, sí reafirmar, durante toda la vida de la Nueva España.

Como novedad añadida a la sencillez espacial del siglo Xvi, las parroquias aportan el crucero y la cúpula. Es decir, dos ejes espaciales nuevos, uno transversal y otro vertical cuyas direcciones a manera de $T$ invertida o triángulo, seccionan el monolítico espacio de las iglesias-caja anteriores y las dividen en dos partes desiguales al formar la cruz, de manera que la sección menor de la nave o "cabecera" queda destinada al espacio sagrado, o sea el presbiterio, y el resto de los brazos, aun los mismos cruceros, quedan para los fieles. El punto de confluencia resulta pues de primordial importancia, ya que es unión y frontera a la vez, y así para acentuar y sujetar mejor este punto y reducir a la unidad la posible disparidad que por diferencias dimensionales pudiera surgir entre nave, 
cabecera y cruceros, aparecen las cúpulas, cuyo espacio sólo es apreciable plenamente cuando se está bajo de ellas, entonces atrae y polariza las diferencias de la masa espacial reduciéndolas a unidad. Cabe hacer notar, que si bien México es quizá el pais con mayor número de cúpulas como ya lo observó Baxter, ${ }^{8}$ sin embargo, éstas no se sujetan al típico patrón europeo, en el que predomina la línea curva en todos los elementos como el anillo, tambor, media naranja y linternilla. Esta circularidad europea, que siempre sugiere rotación, aquí se estatiza y eI mayor porcentaje de las cúpulas mexicanas es el de formas ochavadas. Así se preserva la rectilineidad, y el espacio cupular, que podría obligar a lo curvilineo y esférico, se cubica y faceta, que es tanto como decir que se aquieta. Aun en las bóvedas de media naranja, nunca se pintaron "glorias", con excepción de Villalpando en la catedral de Puebla, ni se perdió la nitidez de la superficie; por el contrario, a esta superficie, se la marcó y dio textura por medio de las decoraciones aplicadas y, según el caso, se procuró acentuar los gajos. La cúpula resulta así una corona solemne, que aunque sin predominar en el espacio interior, como fue la idea renacentista, sin embargo, anuda los simbólicos brazos interiores mientras su volumen marca en el exterior la importancia del espacio que cubre y sobre el que gravita.

Así, la solemne cruz de corazón abultado, se manifiesta clara, tanto en el volumen espacial interior como en la masa exterior, configurando ún concepto de unidad eclesiástica tan gustosamente aceptado, que se convirtió en patrón inamovible, en el que solamente el tratamiento de las superficies sufrió evolución, mas no el de la composición general.

La rectilineidad de plantas y alzados permitió que las iglesias que se levantaron a lo largo de tres siglos pudieran acomodarse en cualquier circunstancia dentro de la retícula de la ciudad y fueran una pro-

9."La Cúpula, es una de las más nobles e impresionantes formas de la expresión monumental, es la característica arquitectónica predominante de este país. México es singularmente un pais de cúpulas. Fuera de Oriente probablemente ningún otro pucblo del mundo tiene tantas cúpulas, en el verdadero sentido de la palabra, es decir, sobre arcos de sólida mampostería Casi todos los pueblos indios del México central tienen su iglesia cupulada. En pueblos insignificantes, que no están en el mapa general, se ven surgir racimos señoriales de cúpulas, que serían un acontecimiento en cualquiera de nuestras grandes ciudades. No hay exageración al decir que las cúpulas se encuentran en este país literalmente a millares." Silvestre Baxter, La arquitectura hispano-colonial en México. Introducción y notas de Manuel Toussaint. México, 1984: p. 13. 
longación de ella; su cubicidad se integra a la cuadrangularidad de las manzanas, y la planimetría de sus alzados es la respuesta correcta a la cúbica estructuración de las poblaciones.

\section{FL BARROCO}

Las curvilíneas iglesias del barroco europeo responden perfectamente a una tradición urbana de irregularidades, pues lo quebrado y pintoreșco que allá es habitual (figura 4), entre nosotros resulta exótico, ${ }^{10}$ y así como una movida planta europea se acomoda perfectamente en un terreno asimétrico o responde con su masa pintoresca a las sorpresivas perspectivas callejeras, las iglesias novohispanas son, con sus volúmenes cúbicos y rígidos, la respuesta lógica y perfecta a un tradicional orden espacial, manifiesto desde la época prehispánica en la planimentría y regularidad de las plazas y centros ceremoniales, y en el virreinato, en los reticulados trazos urbanos (figura 5) y en los atrios del siglo xvı donde lo rectilíneo domina soberano (figura 1). Es más, una conciencia de dilatación espacial y de referencias volumétricas claras explica el hecho de que en nuestro barroco se subrayan determinados elementos como fachada, torres, cúpulas y retablos, descuidando los muros laterales y volúmenes secundarios. Esta aparente discordancia podría ser tomada como un defecto de composición, y hay quien así lo considera; ${ }^{11}$ pero

10 "Guanajuato es una de las grandes ciudades mineras mejicanas del periodo virreinal, $y$, precisamente por serlo, rompe en su traza con la cuadrícula de rigor. Recuérdese el caso comentado de Tasco, y nos referiremos al de Zacatecas. Asentada sobre las misma lomas de las minas, sus calles ascienden tortuosas por las empinadas laderas del estrecho valle. Los desniveles son grandes; ganando en efecto pintoresco lo que pierde en regularidad. Para el europeo, acostumbrado a visitar ciudades encaramadas en lo alto de los montes para defenderse mejor de sus enemigos, el espectáculo no es sorprendente. Para el mejicano, habituado a las poblaciones establecidas por los españoles en las llanuras o en los amplios valles resulta excepcional." Diego Angulo fñiguez, Historia del arte hispanoamericano. Ed. Salvat. Barcelona, 1950, vol. II, p. 751.

11 "Desgraciadamente éstos son en la mayoría de los casos, cosas aisladas del resto del edificio. Ya Quatremere de Quinsy en su Diccionario de la arquitectura, habia hecho notar la falta de relación, en muchos edificios europeos, entre su estructura mural y la cúpula que la coronaba. En México esta falta de relación constructiva y decorativa, constituye un defecto capital. Las más bellas cúpulas parecen grandes bibelots colocados sobre muebles sin terminar. La explicación de este defecto es fácil. Las órdenes religiosas necesitaban muchos templos. Éstos eran construidos 
si observamos los templos virreinales, no sólo como edificios aislados, sino como integrantes de una población y aun de todo el paisaje, salta a la vista el acierto de ese llamar la atención sobre lo que señorea el espacio, o sea, las fachadas como referencia de límite de calles y plazas, y las torres y cúpulas para señalar perspectivas más dilatadas.

\section{TORRES Y CÚPULAS}

Al acercarnos a cualquiera de nuestras características ciudades antiguas, situadas en lomas o en valles, el conjunto urbano se mostraría anónimo, si no fuera porque cobra personalidad e identidad con el sobresalir de cúpulas y torres, ya que aun el volumen de las iglesias se hunde y confunde con el núcleo de construcciones y las fachadas, tampoco se muestran a la distancia, en cambio torres y cúpulas al sobresalir independientes se manifiestan integras, tanto más si acentúan su volumen llamando la atención sobre él por medio de la riqueza ornamental y el color (lámina 4). Torres y cúpulas son elocuentes referencias, pues basta la relación plástica que guardan entre si para darnos cuenta, desde la distancia, de la orientación, dimensión, volumen e importancia del templo al que corresponden, aunque éste propiamente no pueda ser apreciado claramente a primera vista. El esplendor decorativo y la policromía también adquieren, desde lejos, efectividad expresiva, pues al acentuar el individualismo de los elementos que recubren, acentúan la personalidad del monumento y crean un indisoluble compromiso plástico entre la obra y el paisaje, siendo juez y árbitro el espacio. El gran regalo de nuestras ciudades al paisaje son precisamente las cúpulas y las torres, y a su vez el paisaje responde a ellas; éste proporciona la amplitud espacial y la pureza atmosférica para que luzcan como joyas bien engarzadas en él.

No debe olvidarse que la impresión espacial, no sólo depende de la dimensión, sino también de la claridad física, pues un espacio dilatado

de prisa, casi siempre sin un plan general, y como el tiempo que duró la dominación española no fue suficiente para revestir las estructuras, frecuentemente elementales, el interés decorativo fue reconcentrandose en determinados puntos - fachadas, torres y cúpulas. Estas parecieron enfocar desde un principio, todo el sentimiento artístico de la colonia, y ellas constituyen, hoy día, el producto más importante, más típico y más abundante de la arquitectura del virreinato." Doctor Atl, Iglesias de México. Publicaciones de la Secretaría de Hacienda. México, 1924, vol. 1, p. 8. 
se torna inapreciable, sin condición de transparencia, la niebla o el humo son los más incontrolables enemigos del espacio. Lo niegan aunque exista y no es arbitrario pensar que estando nuestro suelo en "Ia región más transparente del aire", con mayor seguridad de su efecto lanza el arquitecto al espacio las cúpulas más policromadas y las torres más ricas en ornamentación y en variedad de formas barrocas, a sabiendas de que la brillantez del sol hará que resalte el color y la transparencia del aire hará lucir el detalle ornamental.

En nuestras poblaciones que aún conservan su proporción urbana de la época virreinal -que es tanto como decir barroca- y en las que la vida moderna no ha modificado su trazo o levantado edificios demasiado altos, se pueden percibir claramente dos niveles espaciales distintos, dos estratos que se complementan. En el inferior predomina la masa sobre el vacío, y está constituido propiamente por la población, esto es, por las manzanas de construcción compacta zanjadas por las calles y dejando de vez en cuando el vacío de las plazas. Este primer estrato es compacto pero bullente, es lo habitado, lo utilizado, aunque rígidamente controlado por la parrilla de calles, donde el espacio fluye en forma rectilinea como líquido canalizado. Sobre ese estrato se extiende un plano, apreciable aunque intangible, que descansa al nivel de las azoteas y a partir del cual se encuentra el estrato espacial superior vacío y abierto al infinito. En él penetran cúpulas y torres con predominio exclusivo y lo hacen engalanándose lo mejor posible, a sabiendas de que serán pobladores únicos de las alturas y que su mayor oficio es puramente estético, pues dignifican y ennoblecen este nivel superior del espacio. *

Puede compararse el aspecto tradicional de las viejas poblaciones con un juego de ajedrez, en el que el trazado de la ciudad con su nítida y rígida cuadrícula, sería el tablero. Sobre de él se levantan torneadas y bellas las cúpulas y las torres, a manera de las piezas de juego, dejando espacios libres que centran y atraen el interés y que son las plazas. Sir torres ni cúpulas estas ciudades serían tan anónimas como un tablero sin uso, y de hecho esto sucede en algunas poblaciones, que por ello carecen de atractivo. Bien lo han sentido los ilustradores cuando aI representar, vista desde lejos, una ciudad, han querido destacar su per-

- Naturalmente que sus autores no imaginaban que algún día, oficinas y departamentos con su vulgar servidumbre de tinacos, antenas y alambrados profanarian este sagrado nivel, destruyendo su tersa armonia $y$ hasta aplastando $u$ ocultando los hasta hace pocos años incuestionables y únicos poseedores: las cúpulas y torres. 
sonalidad y belleza y han vigorizado su lápiz o su pincel hasta exagerar el trazo, al llegar a la representación de las cúpulas y las torres, claros indices de lo mejor que las ciudades ofrecen y de sus gustos y magnifi. cencias.

\section{LAS FACHADAS}

De las fachadas sólo se adquiere cabal aprecio hasta que se está pró. ximo a ellas y se les puede contemplar en toda su dimensión, por lo que requieren un enfoque particular del espacio, una determinada área vacía que les permita lucir completas, un embudo aéreo más o menos profundo, formado por la confluencia de los ángulos visuales del espectador hacia ellas. El barroco, con su irreprimible comunicabilidad, se arrojó con denuedo a las calles $y$, para esto, su arma natural fueron las fachadas. ${ }^{12}$ Fachadas esplendorosas para llamar la atención y en las que se vuelca de tal manera el espíritu del estilo, que bastan ellas para darnos cuenta de las características regionales y de su pretensiones comunicativas; en Italia son siempre ponderadas y no olvidan su abolengo clasicista; son hieráticas en Inglaterra; nerviosas en Austria y Alemania; elegantes y palaciegas en Francia; son eclécticas y multifacéticas en España, y en América se encuentran las más complicadas y exuberantes .

En el caso de nuestro barroco, la fachada no es sino un muro plano lujosamente revestido; es peculiar en ellas una acentuada planimetría y un riguroso orden compositivo. Con sus simuladas estructuras de pilastras y columnas son un emparrillado adherido verticalmente en un muro plano. Constan generalmente de tres calles verticales seccionadas por tres cuerpos horizontales que se superponen, de modo que los tres ejes verticales se equilibran con los tres horizontales, anulándose así mutuamente sus impulsos. Como esquema compositivo resulta de lo más clásico, equilibrado $\mathrm{y}$, por lo tanto, estático y ordenado. Una vez logrado este esquema lógico, se permite a la fantasía que vuelque en él

12 "Función urbanistica de las fachadas independientes del espacio interno. En muchos ejemplos del periodo barroco, la autonomía de las paredes exteriores no es un hecho arbitrario, sino responde a una. nueva visión de los espacios urbanísticos. EA barroco busca una narración. Continúa una delimitación ininterrumpida de la calle - de la plaza, niega la volumetría aislada del Renacimiento. Las paredes de un edificio, y especialmente sus fachadas, no constituyen ya el limite del espacio interno del edificio, sino el límite del espacio interno de la calle o de la plaza, y, por tanta, están caracterizadas en nombre del vacío urbanístico." Bruno Zevi, op. cit., p. 142. nota 9. 
sus frondas en la variedad y cantidad que quiera, que lo invada todo hasta casi octultar la estructura y comunicar con su repertorio de formas un impulso ascensional, un sacudimiento hacia lo alto, muy acorde con los fines trascendentalistas del estilo. Pero siempre queda, y se adivinará en el fondo la inmóvil y segura estructura, como se adivina la inmovilidad del dogma y la coordinación doctrinal tras las mil formas y la relativa libertad que puede adoptar la predicación. Debido al exacerbado derroche ornamental "al lado de las fachadas mejicanas, parece austero lo más profuso y abigarrado del barroco europeo". ${ }^{13}$ $Y$ sin embargo, asombra comprobar que todo esto sucede sin destruir la ordenación, preestablecida por un severo esquema geométrico, y respetando el plano inmóvil en que se despliega.

Una típica fachada del barroco europeo, con sus desplantes ondulados a lo Borromini (lámina 5) o sus avances y retrocesos volumétricos a la manera austriaca y alemana, ofrece y requiere para su comprensión numerosos ángulos visuales. El espectador, para conocerla, puede y debe moverse para descubrir sus numerosas facetas, y seguir el ángulo entre numerosas visuales. Así, el espacio requerido para la total captación de una de esas fachadas, exige movilidad, pues se despliega como un abanico frente al monumento (figura 6) (lámina 6). Son fachadas que se estructuran siguiendo un esquema volumétrico y por tanto son polifacéticas; un exceso decorativo fundaría sus perfiles y las haría confusas, con lo que el ornato resultaría superfluo y en casos estorboso y por ello lo suprimen. Todo lo contrario sucede en nuestras fachadas, cuya estructura se basa en diseños geométricos y no volumétricos, y por lo tanto, su planimetría requiere un exceso de ornamentos que, lejos de perder su trazo, lo acentúan intensificando el claroscuro (lámina 7) .

Así como una ondulada fachada europea exige al espectador que se mueva frente a ella con ritmo de péndulo, nuestras fachadas requieren que el contemplador escape lo menos posible del eje perpendicular a ellas, pues de lo contrario, su composición y perfiles no hacen sino distorsionarse hasta desaparecer. Fachadas como las de el Sagrario Metropolitano o Tepotzotlán, para citar dos casos de los más espléndidos y significativos, vistas tangencialmente se pierden por completo, plegándose en un solo perfil quebrado, confuso y sin interés.

Un esencial frontalismo las rige, de tal manera que el principal mo vimiento que debe seguirse para su aprecio es unidireccional, de avance

19 Marqués de Lozoya, op. cit., p. 226. 
$O$ de retroceso, pero siempre perpendicular a ellas (figura 7). De lejos, el conjunto despliega la nitidez de su composición; de cerca admira la exquisitez del detalle. La riqueza ornamental es un factor primordial para cautivar la atención, pues en su concentración atrae el interés y lo absorbe de tal manera, que todo espacio circundante se abstrae y se dirige a la fachada, al grado que sólo existe en función y al servicio cle ella; la distancia, la luz y el color se aprovechan para dar énfasis a este centro focal. La casi compulsiva intensidad de nuestras fachadas se justifica y explica en su clara intención didáctica; son como una gran página arquitectónica donde los iletrados, como en la Edad Media, deben leer un mensaje doctrinal y, para la sordera del alma, deben oír un canto espiritual. Son verdaderos sermones plásticos inspirados por la fe, estructurados como la doctrina y floridos como la retórica. Cuando se lee una inspirada página o se contempla un devoto lienzo o grabado, éstos no deben moverse en el espacio para poder cumplir su finalidad. De aquí que resulte lógica y no paradógica la peculiar conjunción, en nuestras fachadas barrocas, de rigidez compositiva y desbordamiento ornamental, de monótona planimetría y fantástica variedad.

Una volumétrica y móvil fachada del barroco europeo, con su intelectualismo formal, sugiere la idea de ser un objeto estético al que hay que dar vuelta para admirarlo y gozar su belleza. Una planimétrica y frontal fachada del barroco americano incita más a la meditación que a la sola contemplación, busca tanto enseñar como agradar; es más religiosa que artística. Distinta actitud, distinta intención; por ello, distinta solución. Hay mayor esteticismo en lo europeo y mayor religiosidad en lo americano.

En nuestro barroco las fachadas no solamente debían ser el bello rostro del edificio, sino expresar lo que guardaba en su interior; su función no se cumplía con sólo cerrar y proteger artísticamente un espacio, sino que debía ser un reflejo de su interioridad, espejo de su alma. Así, la fachada se convirtió en retablo, peculiaridad americana y muy especialmente mexicana, que varios investigadores han hecho notar. ${ }^{14}$ Lo anterior sugiere que gozosamente se entroncó y continuó

14 Angulo finiguez, hablando de Lorenzo Rodriguez, tiene un párrafo muy significativo al respecto, al aclararnos cómo "el hecho es que, familiarizado sin duda con la arquitectura de los retablos de estípites, e impulsado probablemente por el ejemplo de Jerónimo de Balbás, Lorenzo Rodriguez logra trasladar estos retablos a] exterior y labrarlos en piedra, y lo consigue con tal acierto, que- su iniciativa forma escuela en breves años. 
la línea de la antigua tradición local, de mostrar el santuario al aire libre, de manifestar el culto al espacio abierto. Díganlo si no, esas fachadas como la del Santuario de Ocotlán, y la de Panotla, en Tlaxcala, - la de San Francisco, en Oaxaca, que cobijadas bajo un gran arco y rehundidas, sugieren la idea de que el presbiterio avanzó hasta el atrio; otros ejemplos más se pueden presentar, como las fachadas de San Juan de Dios en México, de la Salud en San Miguel Allende, o la de San Cristóbal en Mérida, que son verdaderos ábsides externos. Estas fachadas, frente a plazas o amplios espacios libres, son la versión barroca y dieciochesca de las capillas abiertas del siglo xvi, y sólo bastaría poner un altar en el umbral de sus puertas para que fuera completa la función ritual y plástica de esta característica solución mexicana.

Su concavidad podría parecer en contradicción con el sentido planimétrico antes anotado y, sin embargo, no es así, puesto que con ello se recrudece el frontalismo, ya que el espectador queda más obligado que nunca a colocarse en el eje frontal, pues si no, arriesga perder la visión completa de la obra. Bastaría rebasar lateralmente los límites espaciales virtuales de esa especie de pasillo conducente a la fachada, y sujeto al eje frontal, para que aquélla se distorsione, o pierda a la vista su plenitud, al irse ocultando necesariamente por uno de sus extremos a medida que el ángulo visual se aleje de dicho eje frontal. Los límites de visualidad son como rieles espaciales, que existen y que se sienten, aunque no se puedan ver ni palpar. Es curiosa la coincidencia de lo anterior con el dogma o misterio religioso, que en alguna forma tiene relación con la fachada, ya que puede ser aceptado o rechazado; se puede estar dentro o fuera de su proyección, pero la libre elección no altera su esencial inmovilidad.

Lo cóncavo, siempre sugiere introspección y lo convexo extroversión.

"En realidad, el concebir las portadas como un retablo y el trasladar a eflas las formas creadas en éstos, no era nuevo. Ya hemos visto como a fines del siglo xvn se llamaba retablos a las mismas puertas laterales de la catedral de México, pero, tal vez, ahora las consecuencias fueron más trascendentales que en las épocas anteriores por las caracteristicas especiales adquiridas por el retablo. Este habia perdido el sentido de creación arquitectónica renacentista de soportes y entablamentos. Era ya más un muro decorado que una organización arquitectónica con soportes y cubiertas, y algo de ese carácter será lo que distinga a la fachada mexicana de su escuela. No en vano al ensalzar San Vicente en 1768 la fachada del Sagrario nos recuerda según hemos visto, que: 'No cede ventajas la labor de su cantería a las sutilezas que permite la docilidad de la madera para los mayores esmeros'." Diego Angulo fñiguez, op. cit., vol. I, pp. 560-561. 
En América se tiende a lo cóncavo, en Europa a lo convexo. El gusto por la concavidad está muy acorde también con esa actitud de concentración que muestra nuestro barroco. En lo religioso, está manifiesto en lo plástico, en el abigarramiento ornamental, que contrasta con la desnudez en los cubos de torres o de los paños laterales.

En los casos en que no son planas o cóncavas las fachadas mexicanas, de todos modos no liberan al espacio de su servidumbre al frontalismo, ya que cuando adquieren un suave y acogedor término medio entre el plano y la curva, al abombarse o abocinarse, siguen manteniendo el predominio del eje central. Los ejemplos son abundantes, entre ellos podrian citarse como representativos: La Soledad en Oaxaca (lámina 8), la Catedral y el Santuario de Guadalupe en San Luis Potosí, San Francisco en Puebla, la parroquia de Metepec, San Diego y la portada lateral de la Valencia en Guanajuato y Santo Domingo en Zacatecas. Hay muchos otros ejemplos que afirman esa constante del barroco mexicano, que lo hace tan diferente del europeo. En éste la constante es a la inversa, o sea el predominio de lo convexo, que excepcionalmente llegó a mostrarse en nuestro pais, como en los casos de las portadas del "Pocito", en los avances de las portadas de la Basílica de Guadalupe en México, y en la fachada de Ia Compañía en Oaxaca.

\section{LAS PLANTAS}

En gran parte el efecto espacial de toda arquitectura se engendra en la planta sobre la que se desarrolla el edificio, y depende de ella, La planta es para la arquitectura, como su raíz y sustento; los apoyos, columnas y muros, son como el tronco; la cubierta, con todo su complicado sistema estructural, es como las ramas y el follaje. Así, es el todo como un ser vegetal.

Algo de lo más desconcertante en el barroco de México es la repetición sistemática -en las miles de iglesias que se levantaron de la estereotipada composición en forma de cruz latina, cuando no de simple rectángulo. Son muy raros los casos en que se rompió con ese patrón, para erigir los edificios sobre una planta en que predominara la curva, como son: "El Pocito" en la Villa de Guadalupe, Santa María la Redonda, y la desaparecida iglesia de Santa Brígida en la ciudad de México; en las provincias solamente se cuenta con el caso de la Tercera Orden, en Sombrerete, Zacatecas. 
La rareza de estas plantas curvilíneas en México es la excepción que confirma la regla de rectilineidad y planimetría con la que el barroco local conscientemente no quiere romper.

Si en verdad el arte virreinal hubiera sido "colonial" en el sentido tributario, se habrían seguido en forma incondicional, o al menos imitativa, las plantas y la disposición espacial de los grandes monumentos barrocos españoles; pero, vemos que no fue así, pues hay un regusto consciente, y hasta una satisfacción, en la sencillez y claridad de las plantas, que no puede atribuirse a pereza mental o falta de imaginación, ya que los retablas y fachadas superan los modelos españoles en inventiva y variedad formal, como ya lo apuntó Lozoya (ver la nota 2).

Solamente Kubler, en Ars Hispaniae, ${ }^{15}$ publica más de 15 plantas curvilíneas españolas que nuncá llegaron a imitarse aquí, pues el espacio en el barroco mexicano gustó de permanecer fiel a una tradicional cla. ridad y rigidez, que recuerda la dispendiosidad volumétrica y el vacfo monumental, característicos en México desde la época prehispánica. España, por su parte, siguió fiel a su tradición espacial gótica y árabe, con laberínticos interiores en donde sólo el recorrido por ellos aclara la forma del monumento. Queda en España, sobre todo en sus iglesiassalón, algo de mezquita y mucho de catedral gótica, cuando los nume, rosos y enriquecidos apoyos marcan un ritmo, interrumpiendo la nitidez espacial y el silencio de su volumen. Las catedrales de Cádiz y Granada son testimonio de lo anterior, con sus girolas curvas de innumerables

15 George Kubler, Arquitectura de los siglos XVII y XVIII. Ed. Plus Ultra. Arș Hispaniae. v-xrv. Madrid, 1957. Véase también como ejemplo de un caso raro en México el estudio de Justino Fernández sobre la desaparecida Iglesia de Santa Brigida. Publicaciones del II Congreso Internacional de Historia de América, t. III, pp. 438-454. Buenos Aires, 1938.

El análisis, tanto de las plantas como del espacio interior de los más representativos ejemplos del barroco italiano y centroeuropeo, ha conducido a la critica moderna a conclusiones exageradamente enfocadas al carácter o estilo dado por la estructura, poniendo en lugar muy secundario, cuando no excluyente, a lo decorativo, por considerarlo más, como un añadido que como el ingrediente arquitectónico del espacio que es.

Así se llegan a limitar las múltiples posibilidades del estilo y se condicionan sus expresiones con categóricas y excluyentes afirmaciones: "He aquí unos muros levantados. Los unen las bóvedas y una cúpula. Podría nacer una iglesia romántica, una iglesia renacentista, pero no una iglesia barroca." Opinión de Pierre Charpentrat en su, por lo demás, excelente libro dedicado al barroco y llevado dentro de la mejor escuela actual de análisis crítico-arquitectónico. Pierre Charpentrat, Barroco, Italia y Europa Central. Ed. Garriga, S. A. Barcelona, 1964, p. 131. 
efectos de perspectiva. En México no hay una sola girola, ni siquiera en las catedrales, y cuando una planta tiende a rematar en círculo, como en Santa Marfa la Redonda, éste es, simplemente, un ábside hinchado; el espacio no circula, y no siendo un deambulatorio, el eje visual de la nave permanece a la vista rectilíneo, sin fluidez, ni mucho menos con ese ir y venir del espacio elíptico italiano ${ }^{16}$ (lámina 9).

En la rigidez de las plantas mexicanas no hay escapatoria posible; la frontalidad de la fachada y el eje rectilíneo de ella, se continúan y corroboran en el interior; la fachada es el anuncio del remate final constituido por el retablo de fundo. Su frontalismo anticipa también la planimetria de los límites interiores, donde el eje principal es definitivamente aprisionado y lanzado recta y directamente al retablo del fondo, por la delimitación de los muros laterales, que severamente aprisionan la masa espacial y definen sus límites y dimensiones. Una vez logrado ese efecto de nitidez espacial, puede venir cualquier irregularidad $\circ$ añadido secundario, pero ya no perturbará lo esencial del espacio y, así, el aparente caos al añadir capillas o retablos laterales no afecta el sentido de la básica unidad. Es digno de observarse que en nuestras iglesias es frecuente advertir que no existe correspondencia ni simetria entre un costado y otro del monumento; retablos de distinto diseño y dimensión se encuentran frente a frente en las naves y cruceros, o bien, lo que es más significativo, capillas que se abren en los costados invitando a penetrar en ellas, sin que el lado opuesto se equilibre por igual. Lo admirable es, sin embargo, que el espacio esencial de la nave principal, no se perturba. Está tan fuertemente asegurado el fiel de la balanza que no resiente que se cargue alguno de los platillos (figura 7). Volviendo al símil vegetal, la planta de nuestras iglesias barrocas tiene la austeridad y rigidez de un cacto, un órgano o nopal, del que pueden brotar, o no, hijuelos en todo similares a él, pero que en casos de existir no hacen sino complementarle y enriquecerle sin afectar su plenitud, y cuando están ausentes, tampoco le hacen falta.

16 Angulo, refiriéndose al carácter general del barroco mexicano dice de él que: "Siente placer en ver moverse las formas sobre una superficie, muy rara vez hundiéndose en la profundidad. No gusta de mọver los muros del edificio para ofrecernos planos que, con su oblicuidad, confundan nuestro sentido de la orientación en el espacio, y por eso procura que los muros se ajusten a la clara y sencilla trama de la cuadricula. El templo borrominesco de San Carlos en Roma resultaria tan anómalo en México, a este respecto, como en la península. Como veremos, las plantas movidas de este tipo sólo adquieren carta de naturaleza, dentro de la arquitectura hispanoamericana, en el Brasil." Diego Angulo fñiguez, op. cit., vol. II, Pp. 495-496. 
Fachada, nave y retablo, aunados por el eje rectilineo y límites planimétricos, constituyen una unidad en si, que es como un sol independiente, pero en torno al cual pueden girar astros menores, las capillas; que también poseen su propia órbita de distintas calidades y proporciones a él sujetas, haciéndole corte y beneficiándose de él, pero sin afectarle, ni a la unidad de su propio sistema, aunque eso sí, enriqueciéndolo. Quien haya visitado iglesias tan mexicanas como el santuario de Atoto nilco, cerca de San Miguel Allende, o las del valle de Puebla, con su pintoresca irregularidad, o las grandes parroquias, con sus numerosas adiciones, hechas por el tiempo, podrá darse cuenta precisa de lo dicho.

Todo lo contrario sucede en el barroco europeo, pues basta una ojeada a sus plantas representativas para darse cuenta de su multidireccionalidad. El eje principal se fracciona y fuga lateralmente, lejos de encontrar límites murales planimétricos que lo aprisionen o encaucen; éstos tienden a desaparecer, ${ }^{17}$ y la definida nitidez del volumen espacial, que entre nosotros es tradicional y fue preservada por el barroco, en lo europeo es intencionalmente esfumada ${ }^{18}$ (lámina 10). Para ello, desde la planta se buscó la fluidez, la flexibilidad, ${ }^{19}$ que el barroco europeo llevó a sus más caras y representativas exageraciones, sobre todo, en países alejados de la clásica serenidad. ${ }^{20}$ Pero aun en los más fantásticos y deli-

17 "Al límite del espacio le falta el carácter de una terminación definida. El muro está disuelto, la luz penetra a través de sus numerosas aberturas. El edificio ya no está en relación con la tierra y la ley de gravedad parece en suspenso. Así también el espacio carece de una pareja extension: es movimiento, respira y vive," (Lo anterior se refiere a la Iglesia de Peregrinación de Wies.) Hansseter Landolt, "El espacio de la arquitectura barroca." Anales del Instituto de Arte Americano e Investigaciones Estéticas, vol. 9, Buenos Aires, 1956, p. 57.

18 "Resulta que nosotros no podemos visualizar de un golpe la impresión espacial; sólo podemos experimentarla gradualmente. A ello se agrega todavía que la corn. posición decorativa de las bóvedas no destaca las diferentes partes de las mismas, sino por el contrario, confunde sus límites." (Se refiere a la iglesia de Peregrinación de los Catorce Santos en el Valle del Main, Franconia). Hansseter Landolt, op. cit., p. 60.

19 "El muro ondulado de invención de Borromini dio flexibilidad a la piedra, transformó el muro pétreo en un material dúctil. El muro ondulado es el coralario adecuado de los amplios espacios en el sistema de la planta flexible." Giedion, Sigfrido, Espacio, tiempo y arquitectura. Ed. Cientifico-Médico. Barcelona, 1961, p. 119. 3" edición.

20 "Romo siempre rehuyó los extremos. Bernini era napolitano, y Nápoles era española. Hay que dirigirse, pues, a España o Portugal, y desde luego a Alemania si se quiere realmente sentir la emoción de los extremos y de los excesos. El barro: co llegó tarde a estos palses, pero fue acogido con gran fervor. No existen en Italia 
rantes ejemplos del barroco europeo no se llega a un caótico desorden, y el sentido de unidad se salva gracias a una rigurosa simetria, tan imprescindible allá como relativa aquí.

La inestabilidad y el intenso movimiento del espacio europeo requiere un perfecto equilibrio entre los elementos opuestos para evitar cualquier irregularidad, no ya de ornamento, sino de masas y espacio. De otro modo se rompería el equilibrio y se llegaria al desenfreno, donde no cabe ya explicación racional posible, puesto que se entrará en el reino de especulaciones puramente emocionales.

\section{RETABLOS Y BóvEDAS}

Es muy significativo el hecho de que en los libros donde se habla del barroco europeo abundan las plantas de los edificios, para poder aclarar la idea espacial, porque en aquel barroco el movimiento de las plantas, por sí solo, explica y aclara en mucho la forma espacial que sobre ellas actúa. No sucede así en el barroco mexicano, donde las plantas, por su estereotipada monotonía en la distribución y composición, casi no dicen nada; en cambio es necesario ilustrar con fotografías o dibujos los alzados para dar una idea del indescriptible hervor plástico y del esplendor de este barroco (lámina 11). Lo anterior equivale a decir que los planos verticales y los paños delimitadores llevan toda la responsabilidad del estilo, principalmente los retablos y los estucos en las bóvedas. Nuestro barroco comunica a través de ellos el espíritu del estilo $\mathrm{y}$, así, constituyen la voz y el idioma que acogió para expresarse, ya que, sin ellos casi enmudece. Por esto es injusto el juicio tan frecuente como despectivo de considerar que es un "barroco decorativo", como si sólo hubiera sido una artesanía monumental, un juego o delectación ornamental que no alcanzara la categoría de arte mayor y apenas el decoro en lo "decorativo".

Es más comprensivo y lógico suponer que la voluntad formal de nuestro barroco escogió la sencillez espacial y la complicación decorativa como ingredientes esenciales, a fin de compenetrarlos y fundirlos de acuerdo con su peculiar gusto plástico y sus intenciones didácticoreligiosas. A fin de cuentas no es un "arte por el arte" mismo, sino un interpretaciones tan orgiásticas entre realidad y ficción como las que vemos en algunas iglesias españolas y en muchas del sur de Alemania, pertenecientes al siglo xvin." Nikolaus Pevsner, Esquema de la arquitectura europea. Ediciones Infinito. Buenos Aires, 1957, p. 203. 
arte que busca trascenderse. Esa expresión del estilo, más a flor de piel que contorsionando la estructura, bien la sintieron los neoclásicos en el siglo xix, a quienes les bastó arrasar los retablos dorados y rasurar los estucos de las bóvedas para tener espacios claros y solemnes, acordes con su intención clasicista. Bastó la sustitución de la ornamentación simbólica barroca por otra, con el nuevo "buen gusto" neoclásico, para cambiar el "rostro" aunque el esqueleto estructural haya permanecido. En Europa se hubiera tenido que destruir toda la estructura, porque desde la planta a la cúspide, todo es barroco y por ello la ornamentación resulta con frecuencia superflua y hasta estorbosa, pues parece flotar arrebatada en el remolino espacial y detenida sólo un momento en su paso a una meta exterior; de allí el aspecto de cosa innecesaria o desintegrada $\mathrm{y}$, por consiguiente, superficial.

En México el ornato sobrecargado de los retablos, fachadas y bóvedas se muestra, por el contrario, necesario, y, aunque parezca un contrasentido, trepa y se desarrolla en ordenado reposo, jamás se ve arrebatado por el espacio, ni desprendido en inexplicable torbellino; por el contrario, crece y llena todo, pero siempre dentro de un equilibrio seguro y rítmico.

Puede decirse que el barroco europeo se estremece desde sus cimientos, que se agita desde la raiz, y que, por consecuencia, los muros y las bóvedas viven en constante inestabilidad, delimitando un espacio en expansión que desea liberarse de todo límite y que se hincha en forma explosiva, alabea los muros y rasga las bóvedas, que ilusoriamente simulan abrirse con malabarismos pictóricos y ornamentales. Es espacio que se expande galácticamente, fugándose de su propio núcleo; es un barroco esencialmente centrifugo, de limites convulsos tendientes a la indefinición.

Por el contrario, nuestro barroco no se interesa por la agitación o el movimiento estructural, por eso la falta de novedades constructivas $u$ originalidades de plantas, ya que con ese desinterés iba paralela una falta de emulación entre los arquitectos "cultos" o artífices acreditados por buscar hallazgos or:ginales; no se pretendian novedades constructivas, sino un progresivo enriquecimiento emocional-religioso. Por eso tampoco molestaba ni se criticaba la monotonía de las plantas y así en cambio, se aplaudía la "inspirada riqueza de las tallas" en las fachadas y retablos. Es un barroco que tampoco se deleita en curvar los muros y rasgar las bóvedas, que no funde sus límites espaciales, ni pretende ilusiones opticas, sino, por lo contrario, busca la claridad y exactitud dimensional. 
La riqueza decorativa es empleada, no para fundir límites o confundir elementos, sino para perfilar y denotar las distintas partes estructurales. Basta contemplar, como prueba, el indescriptible desarrollo de los estucos y las yeserias, sobre todo en Puebla y Oaxaca que, pese a su insuperable y abigarrada riqueza, siempre perfilan, y hasta puede decirse que con insistencia dibujística, y ponen de relieve las diferencias entre los distintos elementos arquitectónicos. El muro no se funde con la bóveda, ni la pilastra con el arco, y hasta las partes secundarias están vigorosamente marcadas como las aristas y lunetos (lámina 12). En Europa el espacio se fuga, produce ilusiones de perspectiva, y se pintan "glorias" que simulan infinita expansión; aquf, al espacio se le ponen y marcan claros límites, y éste parece que retachara o se estrellara con estrépito plástico en los espumeantes retablos y rugosas bóvedas; en esto estriba el dramatismo de nuestros interiores.

Allá, espacio en fuga, aquí espacio a presión; así se explica la necesidad de la cúpula que sirve de válvula de escape. El gótico, en su elevación total, no necesitó de cúpulas, y el barroco típicamente europeo, con su total expansión del espacio y el movimiento estructural, hizo lo mismo ${ }^{21}$ (lámina 10 ).

En México, de mancra necesaria y obsesiva, aparecen las cúpulas; embudo absorbente para esa presión interior del espacio, que sólo a través de ellas logra escapar, para subir, pero no en fuga, sino severamente conducido a un término simbólico, representado por la alba paloma del Espíritu Santo, que en ningún otro país ha encontrado tantas linternillas-nido como en México. Esa necesidad de dar salida a la presión espacial explica también las extrañas cuanto características soluciones de superposición de cúpulas, que se escalonan creando en su interior un cono irregular por el que asciende en espacio configurando una especie de hueca pirámide polifacética, como sucede en los cama-

21 Hablando del interior de la iglesia de Viergehnheiligen o de "Los catorce Santos". "Aqui, no obstante, la cúpula, parte más importante del edificio, ha desaparecido. En su lugar aparece la reunión de cuatro bóvedas de forma diversa (esférica y elipsoidal) : el coro, la nave y los dos cortos cruceros. La compenetración de los complicados volúmenes de estas bóvedas requiere. el empleo de arcos de doble curvatura. Las correspondientes curvas revelan el sistema en que los diferentes espacios quedan enlazados.

"No hay ninguna partícula de espacio que quede desintegrada del conjunto. La necesidad de pasar desde cada subdivisión a la otra sección del proyecto; que la incluye, produce el efecto final de que todo el interior está en movimiento." Sigfrido, Giedion, op. cit., p. 134. 
rines de las casas de Loreto, en Tepozotlán y San Miguel Allende, para sólo citar dos casos representativos.

En plan comparativo diriamos que el espacio en el barroco europeo tiende a la esfera, (lámina 13) mientras que en el mexicano al cubo (lámina 14). Aquél es un espacio que gira o rueda expandiéndose en torno a un centro, éste permanece sin girar, pero es vibrante, como una masa líquida cuyo continente fuera golpeado y toda ella temblara, pero sin moverse volumétricamente. En nuestro barroco cada fachada, cada retablo, cada bóveda, tienen su vida propia, como animada por una línea sin fin en el plano. El conjunto resulta una suma de remolinos que agitan la superficie y presionan las márgenes, pero sin que la estabilidad se destruya.

En el barroco europeo, sobre todo en los ejemplos de movimiento y riqueza más enardecidas, en Austria y Baviera, el espacio tiene un carácter explosivo, como si la "caja mural" fuera impotente para sujetarlo y todo parece o simula lanzarse al infinito, desgarrando las bóvedas y resquebrajando los muros, que ondulan adquiriendo una textura pastosa y una ductilidad que, con el ingrediente de la ilusión pictórica, resulta evanescente en las bóvedas. Es un barroco transformista que a medida que asciende del cimiento a las bóvedas, parece pasar por los estados de la materia: sólido al contacto de la tierra, líquido en el medio y gaseoso en las alturas. Asi, por sobre pedestales y columnas de perfiles aún recios, aún sólidos, los muros se alabean, los arcos caracolean, y el ornato, como espuma de un mar agitado, se revuelve entre rocallas y florescencias que sugieren un medio acuoso, para que finalmente, en la cúspide, todo acabe disolviéndose, por obra y magia de la pintura, entre vaporosidades lumínicas agitadas por el revoloteo angélico, apenas capaces de contener la muchedumbre de bienaventuractos en marcha al infínito (láminas 15 y 16).

Como reverso de la medalla de ese mundo extrovertido, nuestro barroco se muestra introvertido, pues tiende a la concentración; las estructuras muestran una hermética y nítida cerrazón; lejos están de desgajarse o abrirse al infinito, por el contrario, como cofres donde ordenadamente se guardan tesoros fantásticos, aprisionan el espacio, impidiéndole que, como en Europa, dilapide la riqueza ornamental. $\mathrm{Al}$ paso de los años y con el avance del estilo, la ornamentación simbólica se va acumulando y sedimentando para producir un fértil mundo interior autosuficiente, un mundo de cara a sí mismo, introspectivo, que rumia teología y de 
ella se alimenta en esos jardines de mágicas arborescencias constituidos por los retablos.

En el barroco mexicano el retablo es como un blanco cuyo centro atrae el dardo de la atención; ahí converge todo, pues ahí está concentrado lo esencial; ${ }^{22}$ el altar y el sagrario en la base, y un poco más arriba, el nicho con la imagen venerada, quedan de tal manera entronizados, que el resto es como un gran dosel o marco, y la imaginería y la ornamentación, ya sea vegetal o geométrica, acude múltiple, esplendorosa y reverente a rendir pleitesía a ese centro gravitacional.

Nada se aleja sino que, por el contrario, se coordina y dirige hacia el retablo, y aunque éste se despliega a lo ancho y a lo alto, no rebasa el plano límite que le ha sido marcado. Al respetar sus propios límites y conservar su unidad individual, el retablo adquiere, por consiguiente, autonomía, es una obra en sí aunque se incorpore a un conjunto; no es tampoco un fragmento de ornamentación, entendido éste como algo añadido o a lo más complementario, sino que es un ingrediente arquitectónico necesario para que la obra adquiera su defintivo carácter artístico y simbólico y no quede en simple construcción (lámina 17).

El retablo es como el soplo de vida para la expresión de carácter de nuestros espacios barrocos. Es generador de energia que rompe la serena mudez del espacio haciéndole vibrar y comunicándole ese característico vigor capaz de sacudirnos emocionalmente. Es distinto, aunque equivalente, al arrebato que nos produce el espacio del barroco europeo, y hay que insistir en que existe una diferencia sutil, pero clara, entre la sensación de arrebato y la de sacudimiento. El arrebato sugiere arranque, desprendimiento, ruptura, alejamiento, fuga ... como en lo europeo; la sacudida: fuerza, presión, detención, aprisionamiento ... como en lo mexicano.

La serie de circunstancias religioso-sociales y culturales hicieron que el barroco en Europa se realizara centrifugamente, en tanto que al

22 "Ya sabemos lo sencillo que relativamente fue Churriguera en la piedra y los desnudos que (también relativamente) fueron los barrocos en sus interiores, salvo concentraciones de decoración siempre polarizadas en puntos determinados. El periodo siguiente, el rococó, fue más cálido y abundante en cuanto al adorno interior que el barroco. Una reforma rococó e incluso neoclásica dentro de un templo barroco, siempre es más distraída, policroma y juguetona que el propio interior barroco." A. García Bellido, Estudios del barroco español. Avances para una monografia de los Churrigueras. Archivo Espafiol de Arte y Arqueologia núm. 17. Madrid, mayo-agosto, 1990. 
pasar a América por el tamiz de España, se concibe en forma esencialmente centripeta.

Allá es barroco de lucha, aquí barroco de meditación; justamente por eso Weisbach ${ }^{23}$ le llama al europeo "arte jesuítico", de contrarreforma; en cambio, aqui la lucha es interior, no trata de rebatir, ni de presentar batalla, sino de profundizar en lo aceptado.

Allá es polémico, aqui didáctico; aquél con su actividad, su movimiento, su anhelo y gusto por las "glorias", sugiere la iglesia militante; éste, con su rigidez, su inmovilidad, su celo dogmático, su monólogo formal, y su imaginería poblada de místicos, ascetas y sobre todo de mártires, sugiere la iglesia purgante. Así ambos son distintos, pero complementarios, configuran los dos rostros de la moneda barroca cuyo fin es la adquisición del último y máximo valor: la salvación, sintetizada en el concepto de la iglesia triunfante.

\section{CONCLUSIÓN}

Las observaciones hechas sobre el sentido espacial del barroco mexicano se pueden hacer extensivas a las demás posesiones españolas de América, pues sólo relativamente se puede hablar de originalidades absolutas entre ellas; hay en todos estos países un indudable común denominador espiritual que los liga y que se expresa culturalmente de manera muy enfática en el arte barroco.

Si en la época prehispánica las relaciones en el Continente eran escasas, o si posteriormente a la independencia de los países americanos se ha caído en aislamientos nacionalistas, en la época de la dominación española la unidad espiritual fue asombrosa; virreinatos, capitanías y audiencias fueron como los dedos de una mano, todos distintos en tamaño e importancia, y aun con funciones diferentes, pero siempre obedeciendo a un impulso común. Objetiva o materialmente, nada lo prueba con tanta claridad como el esplendoroso barroco, "la expresión por excelencia" de Latinoamérica, según opinión de varios investigadores.

Así como la comunidad europea produjo el arte gótico, cuando aquello se llamó simplemente "la cristiandad", América produjo su barroco cuando las fronteras no eran aún el rompecabezas actual y cuando el denominador común era "las Indias".

23 Weisbach Werner. El barroco, arte de la contrarreforma. Espasa Calpe, S. A Madrid, 1948. 
Miembro capital de este cuerpo fue la Nueva España y por eso al : hablar aquí del barroco mexicano y sus características espaciales, sin afán nacionalista, tenemos siempre en la mente la hermandad y semejanza con el resto del barroco americano, de la que sólo escapa del tema tratado, por circunstancias históricas y raíces culturales peculiares, el área brasileña.

Con base en las comparaciones que acerca del arte barroco se han hecho en este trabajo, podemos sintetizar nuestras reflexiones conforme al esquema siguiente:

EL BARROCO

Plantas:

Fachadas:

Muros:

Cubiertas:

Ejes:

Composición:

Volúmenes:

EL ESPACTO

Perspectivas:

Limites:

Divergentes

Ondulantes

Carácter:

EN EUROPA

EN AMÝRICA

Curvilineas

Convexas y polifacéticas

Curvos

Indefinición ilusionista

Variedad direccional

Simetria constante

Esférico
Rectilíneas

Cóncavas y planimétricas

Planos

Definición estructural

Unidad direccional

Asimetría frecuente

Cúbico
Convergentes

Vibrantes

Centrípeto. 